\title{
Locating EC Environmental Law
}

\author{
Donald McGillivray* and Jane Holder**
}

Yearbook of European Law, 20 (2001), 139-171

\section{Not Published Version}

\begin{abstract}
Despite prognoses of marginalisation, European Community environmental law has been strengthened, both through Treaty developments, revitalisation of secondary legislation and purposive judgments of the European Court. Concepts once confined to its Environmental Title, such as subsidiarity and integrating environmental considerations into other policy areas, now govern the Community as a whole, being joined and strengthened in this by the new Community objective of promoting sustainable development. This article charts the evolution of these concepts, in effect the 'greening' of EC governance, and also explores the extent to which a mainstream European concept, citizenship, might in turn be greened. The article argues that sustainable development considerations are emerging as a central organising rationale for the Community as a whole. However, EC 'sustainable development' law continues insufficiently to capture environmental values or extended environmental meanings (such as of 'the European Union's environment'), and fails to overcome many of the central difficulties associated with the earlier development of the Community's 'environmental' jurisprudence.
\end{abstract}

Keywords: EC law, environmental law, the European Union environment, sustainable development, integration, subsidiarity, citizenship

\section{Introduction}

From its initial absence from the EEC Treaty, both formally and in practice, environmental policy has moved centre stage in the EC Treaty. In certain key respects, this development has been further strengthened by judgments of the European Court of Justice and by the European Union's international action in this field. Most recently, the Treaty of Amsterdam has altered the objectives of the Community, making the promotion of the core environmental concept of 'sustainable development' a central objective of the revised EC Treaty.' In short, environmental law has now become a structured and embedded body of Community law, a development further reinforced by the extent to which, as a discipline, European environmental law and policy is now firmly on the academic map."

The purpose of this article is to examine this evolution, locating environmental law within the development of EC law more generally. In this context, however, we also consider the use of environmental law to further other objectives of the EU. Our focus, therefore, is the development and application of certain principles with an environmental heritage sustainable development, integration and subsidiarity. The current centrality of these principles in the EC Treaty tells a story of the absorption of the ideas and language of 
environmental policy into the core of the EU's constitution and policy formation processes: the 'ecologisation' of European governance.iii We also identify the application of concepts from the Community's traditional core areas of competence in social and economic matters to the environmental field, most notably citizenship, which has been tagged an example of the 'mainstreaming' of environmental policy. ${ }^{\text {iv }}$

In considering these legal cross-currents, and law's part in furthering and strengthening ideas and values via principles, the main theme is the extent to which recent developments in EC environmental law pose new challenges to legal doctrines and to institutional structures which at present are only uneasily accommodated within existing frameworks. Most early, 'first-generation', Community environmental legislation arose immanently in response to economic law, flanking the market alongside social law. Its accommodation within EC law, legislatively and in judgments of the Court of Justice, ${ }^{v}$ proved to be, on the whole, relatively unproblematic. ${ }^{\mathrm{vi}} \mathrm{A}$ central reason behind the smoothness of this evolution was the emergence of Community environmental law, that is law aimed at the improved management of the environment and of natural resources and firmly anthropocentric in orientation, rather than the emergence at EC level of what might be termed ecological law, stressing the inter-relationship of humans and their natural environment. ${ }^{\text {vii }}$

The recent borrowing of principles with an environmental heritage suggests that environmental law is further embedded in the EU's legal core. However, in this process the principles undergo some change in their role and content. Similarly, elements of citizenship may be 'greened', but not without significant broadening of the concept. In this sense, environmental law at EC level reflects many of the inherent limitations in regulating for positive environmental change, such as adequate representation of environmental interests and the capture of environmental values in decision-making. viii However, there are also limitations specific to the EC context, notably the inadequacy of an environmental agenda within undeveloped areas of EC law such as citizenship, notwithstanding that the EC provides a forum for the mediation of a range of conflicts relating to the balancing of environmental and other interests, primarily trade. We may therefore be entering a phase in which some of the limits of EC environmental law are being reached, and significant challenges to an 'environmental' approach emerging.

The article is broadly structured in three parts. In the next section, we outline what is meant by the European environment, as the subject of the body of Community environmental law. We examine the idea that 'the European Union's environment' (the working term of the European Environment Agency) is contestable ${ }^{i x}$ - the environment is, after all, a many faceted, variable and uncertain thing - and consider the part played by law in the construction of this idea by highlighting various legal representations of the environment. The most important, for the purposes of this article, is the idea of the European environment as a common natural heritage which has currency as representative of a united and integrated Europe. Thereafter, the following three sections consider those principles and concepts with an environmental heritage, and the impact of their upward march within the EC Treaty regime. Finally, in what is a necessarily more speculative section, we consider some of the issues which arise when Community environmental law is examined under the lens of EU citizenship.

\section{The nature of 'the European Union's environment'}

'The European Union's environment' is a central term of reference of the European Environment Agency. ${ }^{x}$ The Agency has, for example, recently attempted to assess the state of the European environment coupled with predictions about its future quality. ${ }^{\mathrm{x}}$ The environment, as portrayed in these reports, is a cluster of 'environmental issues.' ${ }^{\text {'ii }}$ Prime amongst these is the quality of air, water and soil. Considerable importance is also placed on the relationship between environmental quality and human health, an emphasis 
reflected in several of the judgments of the European Court of Justice. This suggests that this environment - its boundaries, characteristics, inhabitants - is a given. This essentialist idea, however, belies considerable complexity and uncertainty. Many different environments exist - urban, ${ }^{\text {iii }}$ wilderness, the indoor environment even ${ }^{\text {xiv }}$ - and the environment might be understood or experienced on different spatial and temporal scales, ${ }^{\mathrm{xv}}$ with the added capacity to change, albeit slowly. ${ }^{\mathrm{xvi}}$

The terms of reference and methodology of the European Environment Agency can be seen as limiting, particularly its apparent failure to capture more complex, extended understandings of environment, shaped by culture and tradition. ${ }^{x i i}$ Arguably, it is through appreciation of such understandings that a real and recognisable change in the quality of 'the environment' might be engendered. ${ }^{\text {xviii }}$ Short of this, the approach taken continues to emphasise quantitative data, along which lines the Agency has recently published its first set of environmental indicators, ${ }^{\text {xix }}$ a precursor to their elevation in the Community's Sixth Environmental Action Programme. ${ }^{x x}$ It is worth stressing that the indicators being advanced at Community level go beyond air and water quality and other traditional environmental sectors such as waste management and ozone depletion to encompass indicators relating to key sectors of the economy and their integration: agriculture, energy, transport and industry (tourism being the one, notable, exception). ${ }^{x i}$ Nevertheless, the indicators are still environmental in the sense that they do not reach beyond environmental issues to try to capture more general 'sustainable development' indicators, the position recently taken in the UK (although these might be criticised as going too far in the direction of subjective 'quality of life' indicators and thus unduly relegating ecological considerations). ${ }^{x i i}$ A more general difficulty with indicators is that even where there is agreement on the factors to be measured, agreeing on the seriousness of the problem is necessarily subjective. ${ }^{\text {xiii }}$

There are also difficulties with the idea of a European environment. 'Europe' is not an identifiable bioregion (a discrete natural region defined according to the lay of the land) ${ }^{\text {xiv }}$ and the physical boundaries of Europe are not settled because of the accession of new Member States, and the variability of the European Economic Area and the European Agreements. The future accession of Central and Eastern European states in particular will radically alter the territory of the EC (and is likely to multiply the sorts of environmental problems which followed the reunification of Germany). ${ }^{x v}$ There is also an element of extraterritoriality: for example, the European Environment Agency includes Norway and other states within its scope, recognising that for some purposes the 'European environment' extends eastwards to Belarus. $x$ xvi

The legal representation of the environment in the EC Treaty and secondary legislation has also been similarly limited and partial, in terms of its content and premises. Most significantly an anthropocentric agenda for environmental protection is pursued, so that the focus of EC environmental law is on protecting the health of humans and certain 'useful' or valued animals (whales, seal pups, and certain other (fur-producing) mammals) $)^{x x v i i}$ rather than protecting the environment for its own sake. This is seen by the legal marginalisation of the issue of eutrophication of waters, when compared to the emphasis placed on safe drinking water. ${ }^{\text {xxvii }}$ And, more generally within water policy, a 'suitable for use' formulation has been the rule, combined with standards for various water uses, rather than rights or entitlements to water of a particular quality. ${ }^{\text {xxix }}$ This agenda is also striking in the case of the Habitats Directive, ${ }^{x x}$ in which the destruction of a habitat for 'development' is provided for, so long as certain procedural requirements are fulfilled. ${ }^{\mathrm{xxx}}$ This demonstrates clearly the institutional strains at work which force the institutions of the Community (and in particular the Court of Justice) to fit environmental problems into a human welfare framework.

The heritage of the anthropocentric agenda in the EC is in the emphasis on the 'Human Environment' in the Stockholm Declaration of the United Nations Conference in 1972 which prompted action on the part of the European Economic Community. ${ }^{x x i i}$ The 
constraints of Article 235 of the EEC Treatyxxiii (a legal base for Community action on the environment before 1986) also contributed to this. ${ }^{\text {xxxiv }}$ Legal measures adopted under this Article were to attain 'in the course of the operation of the common market one of the objectives of the Community'. In the case of environmental measures, this objective was interpreted as improving the living and working conditions of the peoples of Europe. 'Purer' environmental objectives which were expressed in some of the early policy documents, action programmes, and legislation ${ }^{\mathrm{x} \times \mathrm{v}}$ were therefore fitted within the constraints of, in policy terms, a conservative European Economic Community. Whilst ex Article 235 EEC (now Article 308 EC) has been regarded generally as an all-embracing legal base, 'a true locus of expansion', ${ }^{x x v i}$ in the environmental field it restricted the type and content of legislation.

There are clearly gaps in the substantive law most notably in areas such as remedying the

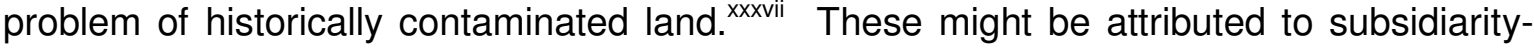
related issues concerning the proper level of regulation. They might also be explained by reason of the importance of Member States' control over land and energy, as symbols of sovereignty and self-sufficiency, ${ }^{x x v i i i}$ although there is a qualification in that EC environmental law acts upon those areas of the environment which are perceived as least economically vital, typically nature conservation. Even allowing for these explanations, however, certain omissions in EC environmental law derived from its anthropocentric orientation underlie the central philosophical and political distinction between 'environmentalists' who adopt a technicist and often managerial stance towards the environment and 'ecologists' who view human activities as embedded in nature, and bioregions as determinative of action, government, and law. ${ }^{\mathrm{xxxix}}$ Although the distinction between the two extremes is often exaggerated, it is important to recognise that, in its purpose, content, and scale, EC environmental law is an implicit rejection of ecological thought. This might be supported by reference to limited legislative action so far in areas such as strategic environmental assessment, providing for an assessment of the environmental effects of certain plans and programmes (but not policies). ${ }^{\mathrm{xl}}$

The scope of EC environmental law may also be illustrated by the reasons on which regulation is premised. Alongside economic spillovers and the pursuit of a 'level playing field' across the Community, the transboundary movement both of pollutants and of pollution was a key justification for early community law. ${ }^{\text {li }}$ In recognising the irrelevance of borders in such cases, the 'environment' acted as a symbol for the advantages of joint action in Europe; the environmental agenda corresponding well with the idea of the EU 'as a polity which transcends state boundaries'. xlii More recently, a greater sensitivity to actual cross-border dimensions to environmental harm and its regulation is emerging, evidenced for example by cross-frontier consultation requirements now contained in revisions to the leading directives on environmental impact assessment, ambient air quality assessment and management, and the control of major accident hazards, and in the water framework directive. xliii $^{\text {. }}$

With a different emphasis, however, EC environmental law is now developing the idea of shared heritage of the European environment. This is a more complex but possibly firmer foundation for environmental law than the regulation of transboundary pollutants and pollution. It has found expression not merely in legislation but also in judgments of the Court of Justice. The shift towards a more inclusive, less functional premise for environmental law may first be seen in cases in which the Court's interpretation of air quality Directives had the effect of giving individual citizens a right to clean air. ${ }^{\text {xliv }}$ This has been lauded as the first stirrings of a public environmental 'trust', ${ }^{\prime}$, although in a limited form for enforcement purposes rather than as part of a broader citizenship agenda. xlvi Since then, the Court of Justice in Lappel Bank has reinforced that the Wild Birds Directive accords protection to species constituting 'a common heritage of the Community', xlvii an aspect of the Directive found to be capable of subjugating the national interest element of land use. xlviii Recognising this, the Court sought to deny the significance of territoriality 
rather than affirming it as in previous cases such as Red Grouse in which the Court of Justice held that the Netherlands could not ban local sales of birds killed legally in other Member States if they were neither migratory nor endangered within the meaning of the Directive. ${ }^{\text {xix }}$ In this respect, the Court pursued an ecological objective, but this is not the general approach of the EU. More important is the Court's broadening of the language of the Directive, which speaks of 'such species ... constitut[ing] a common heritage'. The Court may here reflect a widening of the language of commonality found in the preamble to the Habitats Directive ('the threatened habitats and species form part of the Community's natural heritage')' and more broadly the absorption of the concept of 'commons' from international environmental law. Pursuing this idea in Lappel Bank, the Court spoke the language of integration - of common ownership of a Europe without borders in a real sense and common responsibilities. This idea, in law, of shared ownership of the European environment, is central to its legitimating force. The Court appears reluctant, however, to refer to commonality in relation to other environmental resources.i This may be indicative of the problematic limits of a shared ownership approach to integration, some of which are addressed by recourse to the principle of sustainable development.

\section{Sustainable development}

Following the Treaty of Amsterdam, the international principle of sustainable development now forms part of the Community's raison d'être in Article 2 EC: 'Determined to promote economic and social progress for their peoples, taking into account the principle of sustainable development and within the context of the accomplishment of the internal market'. The principle has also been added to the Treaty on European Union so that amongst the objectives of the Union is now listed: 'to promote economic and social progress and to achieve balanced and sustainable development'.ii The principle therefore provides a foundation for EC action in general rather than a more limited field of application, the formation of environmental law and policy.

The principle of sustainable development can be traced to the 1972 United Nations Conference on the Human Environment in Stockholm, but gained currency in the 1987 Report of the World Commission on Environment and Development (the 'Brundtland Report') which defined it as 'development that meets the needs of the present without compromising the ability of future generations to meet their own needs'. lii The inclusion of sustainable development in the EC Treaty thereby introduces for the first time an intergenerational element into EC law. The centrality of the principle in the Union's treaties may be seen primarily as a response to the Member States adopting sustainable development as a guiding principle in national legislation and policy documents, thereby discharging their obligations under international law. ${ }^{\text {liv }}$ It is also a testament to the persistent and effective lobbying by bodies such as Greenpeace International, the Institute for European Environment Policy, the European Environmental Bureau, Friends of the Earth and WWF (formerly the World Wide Fund for Nature). ${ }^{\text {Iv }}$

Although its firm position in the EC legal order suggests some consensus about its meaning and significance, sustainable development is a deeply contested concept. ${ }^{\text {Ivi }}$ This is not least because of the 'business as usual' philosophy, expressed in the Brundtland Report ${ }^{\text {vii }}$ and close association with 'environmental modernisation' in which an efficiency oriented approach is pursued, and economic and environmental interests are purportedly integrated into decision-making in such so-called 'win-win' solutions. In other words, this is an approach which sees environmental protection as less of a threat to the economy than an opportunity, and advocates the integration of environmental factors and interests into broader decisionmaking, so far at the cost of a more overtly ecological approach. ${ }^{\text {Iiii }}$ The principle of sustainable development thereby provides a continued link with economic priorities, even at a time when the EC Treaty ${ }^{\text {lix }}$ and certain judgments of the Court of Justice portray a decoupling 
of environmental policy from its traditional economic base. ${ }^{\mathrm{x}}$ This economic orientation of the principle may be seen in the continued retention in the EC Treaty of terminology derived from the Treaty on European Union ('sustainable growth'). ${ }^{\mid x i}$ This points to Community adherence to the 'weak' version of sustainable development generally preferred by governments of the Member States. In other words, sustainable development provides an environmental example of the familiar combination of the aspirational and the pragmatic which has characterised the evolution of Community law more generally.

Legal definitions of the concept of sustainable development as a matter of European law are few, and the term is not directly defined in the EC Treaty. However, recent proposals on supporting environmental integration in developing countries attempt to put some flesh on the bones. Thus, recent changes to replace the Regulation on environmental measures in developing countries in the context of sustainable development ${ }^{1 x i}$ provide that: "sustainable development" means the improvement of the standard of living and welfare of the relevant populations within the limits of the capacity of the ecosystems by maintaining natural assets and their biological diversity for the benefit of present and future generations'. 'xii This approach elevates the notion of environmental limits in a quite different manner to that taken in the EC Treaty, which speaks instead of one objective of Community environmental policy being the 'prudent and rational use of natural resources'. of sustainable development are being played out in different contexts in what appears to be a quite deliberate manner. ${ }^{\mathrm{IxV}}$

Short of the Treaty itself fleshing out what sustainable development, or 'sustainability', is, the Court of Justice has declined to look to such guidance as is found in the Community's environmental action programmes, most recently the definition offered in Towards Sustainability. ${ }^{\text {Ixvi }}$ And, in cases in which issues of sustainability are at their core, for example on the interpretation of the Directive on environmental assessment, ${ }^{\text {Ixvii }}$ the Court of Justice has adopted a purposive approach, referring to the necessity of interpreting the Directive so as to confer a high level of environmental protection, but has failed to explain this in terms of 'operationalising' sustainable development. ${ }^{\text {Ixviii }}$ This may be compared with the approach adopted by the International Court of Justice, ${ }^{\mid x i x}$ and to some extent the approach of the Commission at a policy level. ${ }^{\mathrm{Xx}}$ However, A-G Léger's Opinion in First Corporate Shipping ${ }^{\mathrm{xxi}}$ may represent something of a development in terms of the Court of Justice's conceptualisation of sustainable development. The Opinion aligns the aim of the Habitats Directive with sustainable development. Drawing on the Directive's preamble (which describes the Directive as making a contribution to the general objective of sustainable development) the Advocate General considers that sustainable development 'emphasises the necessary balance between various interests which sometimes clash, but which must be reconciled'. This assisted in reaching the conclusion that in deciding which sites to propose or when defining the boundaries of such sites for the purposes of the Habitats Directive, the Commission (in agreement with the Member States) must assess the interests concerned, ascertaining whether human activities in the area may be reconciled with the objective of biodiversity conservation. While the Court was able to dispose of the case on narrower grounds without discussing sustainability, this view represents a considerable departure from the ECJ's case law on the Wild Birds Directive which consistently held that only objective ornithological criteria could be used in designating bird habitat sites for protection. ${ }^{\text {Ixii }}$

The apparent lacuna in the Court of Justice's handling of the principle might be explained by its relatively recent addition to the Union Treaties ${ }^{1 \times x i i i}$ and its close identification with policy formation, rather than as a justiciable source of rights. It is indeed policy making that sustainable development is likely to influence further, for example in the direction of an overarching 'First Sustainable Development Strategic Forum' embracing also the development of a Sixth EC Environmental Action Programme. ${ }^{\text {Ixiv }}$

\section{Integration}


An imperative of sustainable development is the integration of environmental protection requirements into the social and economic dimensions of other policy areas. This suggests the desirability of recognising existing connections and fostering interrelations between Community institutions and the Member States, to reduce the possibility of the environment being discounted or marginalised in decision making. Whilst integration provides a template for the development of the EU as a whole, and integration clauses in the EC Treaty refer to areas other than environmental policy, ${ }^{1 \times x v}$ it has particular significance in the environmental field. This is because of the environmentalist's argument that environmental protection requirements should necessarily form part of all areas of life. ${ }^{I \times x v i}$ Integration therefore provides a mechanism whereby the linkages between the social, economic and environmental spheres, identified by sustainable development, may be acted upon. ${ }^{\text {Ixvii }}$

Even in the absence of an integration principle, the Community has for some time been regarded as a space for the important integration of valued objectives. Most notably, there were relatively early attempts at integrating environmental considerations into regional policy, although these are still the subject of fierce criticism. ${ }^{1 \times x v i i i}$ However, the central locus of integration has been through the Court of Justice holding environmental protection to be a mandatory requirement justifying restrictions to the free circulation of goods under Article 28 EC (ex Article 30) where indistinctly applicable measures are taken. ${ }^{1 \times 1 x}$ The judicial creation of mandatory requirements has overcome some of the limitations inherent in Article $30 \mathrm{EC}$ (ex Article 36) of the Treaty which, despite pressure for change at the pre-Amsterdam Intergovernmental Conference, continues to exclude environmental protection objectives from its list of justifiable prohibitions. A glimmer of hope for the reinterpretation of what are essentially sanitary and agricultural protections, however, can be seen in Bluhme. ${ }^{\mathrm{Ixx} x}$ There, the Court of Justice held that a national legislative measure prohibiting the keeping on a Danish island of a species of bee other than the native subspecies must be regarded as justified, under Article $30 \mathrm{EC}$, on the ground of the protection of the health and life of animals, thus elevating biodiversity conservation through protection of the life of potentially affected species. However, the judgment goes further still by allowing trade-related protection for local colonies of species regardless of whether such a colony might be deemed a distinct species or subspecies. So long as the population affected has characteristics distinguishing it from others, this makes it worthy of protection, not merely from a scientific perspective but perhaps also for its cultural significance. Cases such as Bluhme highlight that the Court at least provides a unified forum for the resolution of conflicts between trade and environment, even if its rules on standing still serve to exclude certain environmental voices ${ }^{1 \times x \times i}$ and the actual resolution of trade and environmental objectives remains elusive. ${ }^{\text {Ixxii }}$

A more certain approach to integration, less reliant on litigation which continues to favour trade-related interests, ${ }^{1 \times x x i i i}$ may flow from the application of a legal principle of integration, the heritage of which is in the Environment Title of the EEC Treaty, ${ }^{\text {lxxiv }}$ inserted by the Single European Act 1986. This was subtly strengthened by the Treaty on European Union 1992. ${ }^{1 \times x \times v}$ The Treaty of Amsterdam further enhanced the principle by elevating it to a general principle of the EC Treaty, banishing any view that it applied only to 'other [explicitly mentioned] Community policies', and twinning it with sustainable development. ${ }^{\text {Ixxvi }}$ Although undoubtedly strengthened over time (suggesting that it has been seen as increasingly significant, or, perhaps, in need of clarification), the forms of integration relate mainly to the integration of policy areas and the promulgation of 'horizontal' or cross-media legislation. A legal analysis of the principle, however, suggests that integration is primarily a procedural requirement. ${ }^{\text {Ixxvvii }}$ Although not purely exhortatory, ${ }^{\text {Ixxxviii }}$ neither is it clearly justiciable. ${ }^{\text {Ixxix }}$ And, although the legal status of the principle of integration has been debated in disputes over the legal base of a measure,$^{\mathrm{xc}}$ questions remain as to whether the principle may constrain Community activities which fail to reflect the integration concept, or require positive steps to be taken. ${ }^{\text {xi }}$ Beyond limited hard legal effect, therefore, the elevation of the integration principle in the EC Treaty has been felt most at the policy and institutional level. Thus, it has imposed an obligation on the part of the Directorates-General to consider environmental protection requirements as part of their respective policy areas. Triggered by the Cardiff 
European Summit, ${ }^{\text {xii }}$ there is an expanding number of discussion documents that pertain to 'integrate' the environment into other policy areas. These adopt either a bilateral approach to integration (i.e., the integration of 'the environment' into a specific sector), ${ }^{\text {xciii }}$ or, increasingly, a multilateral approach whereby more complex and complete patterns of co-operation are evolving. ${ }^{\text {xciv }}$ Elsewhere, it has led to a range of institutional developments such as designated environmental liaison officials in other Directorates-General, in effect a lukewarm version of the Greening Government initiative in the UK. ${ }^{\mathrm{xcv}}$

Legislation with an avowedly integrationist intent has ensued. One recent example is Regulation 1257/99 on support for rural development ${ }^{\mathrm{xcvi}}$ which, by strengthening agrienvironmental measures, attempts to integrate environmental concerns into the Common Agricultural Policy under the Agenda 2000 reform process. However, such reforms should perhaps be seen as performing a legitimating function for the purpose of excluding, or 'greenboxing', agricultural grants and subsidies from the purview of the World Trade Organisation. A further category of integrationist measure relates not to the internal procedures of the Community institutions, but rather aims to more fully integrate decision making in the Member States. The Directive on project-based environmental assessment is an early example. A more fully developed approach to assessment is taken in the recent proposals on strategic environmental assessment, noted above. ${ }^{\text {xvii }}$ In similar vein, attached to the Treaty of Amsterdam is a Declaration ${ }^{\text {xviii }}$ that 'the Commission undertakes in its proposals, and that the Member States undertake in implementing those proposals, to take full account of their environmental impact and of the principle of sustainable growth'. However, this falls some way short of a requirement that impact assessment be carried out and is notable for its reference to 'growth' rather than 'development'.

Elsewhere, the Directive on integrated pollution prevention and control offers an example of the advantages and potential scope of an integrated approach. ${ }^{\text {xcix }}$ As well as rejecting a media-based approach to pollution control, which is itself the antithesis of an integrated approach, the Directive reflects a recognition that integrated pollution control requires the regulation of 'inputs' as well as 'outputs', namely energy and natural resources, giving it certain qualities relating as much to environmental management as to environmental protection. ${ }^{c}$ The inclusion of some agricultural processes within the Directive's scope further suggests some progression towards a more holistic approach to the environment. A similarly holistic approach is also evident in the Water Framework Directive ${ }^{\mathrm{ci}}$, which links water quality and quantity objectives, although takes an insufficiently integrated approach, e.g., energy consumption in meeting water quality standards is not addressed.

There has therefore been much action in terms of documentation and some notable examples of directives taking an integrationist approach. ${ }^{\text {cii }}$ But, taking a broad view, there are few identifiable, 'hard' consequences of the principle in terms of decision making. The decision to proceed with the completion of the internal market, without any rigorous examination of the likely effects on the environment, ${ }^{\text {ciii i }}$ is one example, such that the policy decisions on the bolsters to the single market, such as the trans-European network, may be seen as examples of profound 'disintegration'. civ Perhaps most significant is research that suggests that the moves towards greater integration of policy areas can actually lead to marginalisation of the environmental agenda, and non-environmental interests and considerations influencing environmental interests as much as vice versa. ${ }^{\mathrm{cv}}$ Arguably, the proliferation of integration duties may weaken the concept such that the environment loses any distinctive legal status in the Treaty. ${ }^{\text {cvi }}$

\section{Subsidiarity}

The third principle we consider in the context of the greening of EU governance is subsidiarity, a version of which was included in the Environmental Title following the Single European Act ${ }^{\text {cvii }}$ before the principle gained more general legal currency at Maastricht. Like other provisions of the SEA relating to the environment, however, the insertion of a 
subsidiarity-type provision confirmed and legitimated existing practice, in this case entrenching (albeit to a limited extent) an existing sensitivity to questions of scale. Thus, the First Environmental Action Programme referred to five possible levels of action - local, regional, national, European, international - and the need 'to establish the level best suited to the type of pollution and to the geographical zone to be protected' ${ }^{\text {cviii }}$ Of course, for some Member States at least, the initial insertion of a subsidiarity-type provision in the EEC Treaty was to prevent an undesirable extension of Community competence rather than anything with wider impact. ${ }^{\text {cix }}$

The more general subsidiarity provision inserted at Maastricht reflects a concern with the appropriate level of decision-making. This, as with the version of subsidiarity originally contained in Article 130r(4) of the EEC, again juxtaposes Community and Member State action, using 'effectiveness' as its true measure. ${ }^{c x}$ Necessarily this has implications for values related to processes rather than outcomes. ${ }^{\text {cxi }}$ Thus while there are a number of provisions of EC environmental law which require or promote a measure of public involvement, a difficulty is that this occurs against a background in which procedural values are fundamentally downplayed. ${ }^{\text {cxii }}$ A further implication is that the approach in Article 5 EC (ex Article 3b), which conspicuously eschews the citizen-centred approach to subsidiarity taken in Article 1 of the TEU (ex Art. A), blocks out an important conceptual space for the ecological citizen, avoiding consideration of the local or the 'domestic' as worthy of Treaty-based protection. ${ }^{\text {cxii }}$ In any event, the fluid boundaries of environmental law, and in particular moves to integrate environmental concerns into other policy sectors, pose a particular challenge to the idea of a strict division between exclusive and shared competence. cxiv This is further complicated by the difficulty, in the environmental sphere as elsewhere, of drawing sharp distinctions between the local and the global and all points in between.

In addition, continuing attention to effectiveness of outcome clashes not merely with other valuable aspects of regulation, such as process values, but also with the realities of existing EC environmental law. Many new environmental measures move away from traditional 'command and control' regulation and are difficult to judge on normal 'effectiveness of outcome' grounds. Recent amendments to the Directive on environmental impact assessment, for example, retain its procedurally-focused mechanisms based on preventing adverse environmental impact at source, although the Directive is not directly assessed against this objective, either quantitatively or qualitatively. ${ }^{\mathrm{cxv}}$ On the other hand, while the economic costs and benefits of taking action at EC level are captured in the Commission's fiches d'impact, political values grounded on more aspirational environmental objectives may in practice prove to be overriding. ${ }^{\text {cxvi }}$

Because subsidiarity-type concerns related to 'who does what' have always influenced environmental policy, Treaty-based provisions have impacted most in relation to 'what it is they actually do', conflating subsidiarity with pressures towards deregulation. ${ }^{\text {cxvii }}$ While the pace of new environmental legislation undoubtedly slowed following completion of the internal market, and some inert proposals were, for the time being, withdrawn, the greatest impact has been the subtle reorientation of new proposals towards greater flexibility. This is seen most clearly in the exercise of discretion, primarily at national level, and both legislatively and judicially: changes to the form and intensity of legislation, and a greater willingness to apply and interpret this flexibly and to bolster this approach through a preference for decentralised enforcement methods. ${ }^{\text {cxiii }}$ Nevertheless, the general endurability of existing EC environmental legislation and proposals for new law is striking. Central to this have been the pre-existing twin sensitivities to issues of scale in decisionmaking, as well as leaving the details of the balancing of environmental and other objectives to the Member States. ${ }^{\text {cxix }}$

More specifically, many directives identified as requiring simplification in the postMaastricht period (especially those relating to air and water quality standards) have been renewed or are close to revision, albeit that they are subject in differing respects to 
subsidiarity. For example, there has been some shift in the Directive on drinking water quality towards regulating only for essential quality and health-related parameters, while Member States are to be given greater flexibility in monitoring water quality. ${ }^{\mathrm{cx}}$ Current thinking on amending the Directive on bathing waters might, for the first time, make distinct provision for different waters depending on natural differences in, e.g., $\mathrm{pH}$, turbidity and salinity, requiring standards to be set with respect to what is 'normal', which will vary across the Community. ${ }^{c x i}$ This approach would take differences in environmental assimilative capacities seriously while, in theory, providing for common minimum health and amenity standards. And in relation to air quality, the adoption of the Directive on ambient air quality assessment and management ${ }^{\text {cxxii }}$ has put to rest concerns that the Community had, by the mid-1990s, abandoned, at least temporarily, recourse to quality objectives in this sector in favour of emissions standards, seemingly because of the greater flexibility afforded by process-based controls. .xxiii $^{\text {che }}$

In addition, controversial provisions of existing Directives in these key policy areas have, for a range of reasons, endured. These include the background presence of international commitments or exhortatory standards, such as the role of World Health Organisation standards in guiding drinking water and air quality law, but probably also include the impact of the precautionary principle in entrenching existing provisions of environmental legislation which might not otherwise remain. Finally, renewed commitment to existing policy areas involves little risk of losing symbolic capital. Similarly, new legislation has been adopted, or proposals remain active, in every key area where, post-Maastricht, at least some Member States were actively hostile to legislative development. ${ }^{\text {cxiv }}$ Notable here is the adoption of Directives on packaging waste and landfills, ${ }^{\mathrm{cxv}}$ and the prospect of legislation on strategic environmental assessment ${ }^{\text {cxxvi }}$ and environmental liability. ${ }^{\text {cxxvil }}$ Even a Directive on zoo animals has emerged, albeit one concerned with the contribution of zoos to public education about biodiversity conservation rather than welfare concerns, ${ }^{\text {cxxviii }}$ illustrating continuing ambiguities in the Community's involvement in animal welfare. ${ }^{\text {cxix }}$

While generalisations are problematic, some trends seem to emerge. Firstly, minimum harmonisation remains the preference, while the scope for Member States to maintain or adopt higher national standards will, in practice, increase. ${ }^{\mathrm{cxx} x}$ Linked with this, genuinely 'framework' directives have yet to emerge, although the Water Framework Directive will alter this. (Whilst its pursuit of water quality of 'good ecological status' may prove elusive, its problematic approach combining emissions and quality standards ${ }^{\mathrm{cx} x \mathrm{i}}$ is accompanied by a no deterioration provision which, in principle, should mean no weakening of existing provisions.) A continued use of framework directives in the sense of 'umbrella' directives providing a general basis for more detailed controls, however, can be seen in the air quality sector, with 'daughter' directives finally emerging. ${ }^{\text {cxxxii }}$

Secondly, Member States' discretion at the stage of implementation persists, although procedural constraints may be attached. Time-limited derogations to particularly affected Member States continue to be used, while central regulatory terms are left undefined or intentionally vague. ${ }^{\text {cxxxiii }}$ More generally, a narrow view of taking local environmental conditions into account is emerging more explicitly, even if this is within procedurally constrained parameters. ${ }^{\text {cxxxiv }}$ This approach looks to physical environmental features rather than situatedness or 'closeness to the citizen'. Further, a divergence is emerging in relation to measures requiring the designation of sites and the application of protective regimes for pollution control therein, an approach traditionally seen as something of a halfway house between emission and target standards. This is the approach taken under the Urban Waste Water Treatment Directive, under which areas sensitive to sewage effluent discharge must be designated and the courts have given Member States little discretion is doing so. ${ }^{\mathrm{cxx} x \mathrm{v}}$ In another area the Court of Justice continues to deliver fairly strongly worded judgments on the designation of conservation areas, including important judgments on the sufficiency of a Member State's overall designation. Thus the jurisprudence of the Court in relation to sites of conservation importance has moved 
beyond judgments on whether individual sites should have been designated to ruling on whether Member States have designated a sufficient number of sites or total area for safeguarding measures to apply. ${ }^{\text {cxxxvi }}$ However, this approach tends to be followed where designation does not entail the 'preservation' of such areas, but allows economic considerations to be weighed when deciding on questions of land use. By contrast, where designation 'matters', the Court has, at least in certain situations, shown a certain measure of flexibility towards Member State discretion. ${ }^{\text {cxxxvii }}$ Under the Directive on Agricultural Nitrates, ${ }^{\text {cxxviii }}$ for example, designation as a nitrate vulnerable zone requires the drawing up of action plans for the reduction and prevention of water pollution from nitrates and agricultural sources. Hence in $R v$ Secretary of State for the Environment and Minister of Agriculture, Fisheries and Food ex parte Standley and Metson the Court of Justice held that 'Community law cannot provide precise criteria for establishing in each case whether the discharge of nitrogen compounds of agricultural origin makes a significant contribution to the pollution .... The Directive may thus be applied by the Member States in different ways'. ${ }^{\text {cxxix }}$

Finally in this context, there is a continued resistance to transferring inspection and day-today enforcement powers to the EC level. In part this is because of the loss of symbolic capital involved $^{\mathrm{cxl}}$ but no doubt it is also for the more pragmatic reason that EC-level inspection and enforcement may simply be too challenging a task. Instead, the onus has so far been placed on other mechanisms and institutions such as the role of the European Environment Agency (in gathering information) and the EC Network for the Implementation and Enforcement of Environmental Law (IMPEL) (which promotes the exchange of information and expertise between regulators with a view to developing greater consistency in enforcement). There is the prospect, however, of a Recommendation on minimum criteria for environmental inspections which would require Member States to draw up plans covering both routine monitoring of industrial activities regulated under Community environmental law, and non-routine follow-up inspections. ${ }^{\text {.xli }}$

Thirdly, there has been less resort to a widening of the range of regulatory instruments than the Fifth Action Programme perhaps envisaged. Although market-based instruments have emerged in relation to vehicle emissions and fuel quality, ${ }^{\text {cxlii }}$ where voluntary agreements with the car industry have also been negotiated by the Commission, ${ }^{\text {cxliii }}$ the wider use of economic instruments remains a vision rather than a reality. ${ }^{\text {cxliv }}$ Again for reasons related to symbolic capital, proposals for a carbon/energy tax, and revised proposals for an energy products tax, have stalled. ${ }^{\text {cxlv }} A$ resurrection in response to the demands of climate change seems unlikely, with the flexibility of emissions trading, either between the Member States or, more likely, individual companies, emerging. ${ }^{\text {cxlvi }}$

Finally, subsidiarity as a legal concept both fails to resolve fundamental issues about the allocation of responsibility and, as importantly, the framing of the kinds of questions that determine such decisions. ${ }^{\text {cxlvii }}$ While there have been improvements in the direction of wider public consultation on certain proposals, experience has been mixed. ${ }^{\text {cxlviii }}$ And current proposals continue to downplay public involvement after implementation, generally by adopting a technocratic approach to what are wider issues. ${ }^{\text {.xlix }}$ As Chalmers points out, opportunities for public participation in the key Directives on IPPC and environmental impact assessment come in only after the process of industry self-review has taken place, ${ }^{\mathrm{cl}}$ which broadly parallels approaches elsewhere, for example under the Works Council Directive. ${ }^{\text {li }}$

\section{Citizenship}

In this section, we consider the extent to which EC environmental law might be conceptualised within a framework drawn from the EU's nascent attempt to carve out a European concept of citizenship. ${ }^{\text {clii }}$ Although much of this concept is currently a loose construction of free movement and equal treatment rights, ${ }^{\text {cliii }}$ we examine the extent to 
which EC law has begun to construct the EC 'environmental' citizen by the use of existing approaches and incremental development of generally-accepted citizenship claims. Attempts to develop the European environmental citizen, notably in relation to public participation, have often been driven by the need for greater enforcement of existing EC environmental law, long-recognised as a serious weakness. ${ }^{\text {cliv }}$ Furthermore, bolder proposals in this area, such as the formal entrenching of environmental 'rights' at the EU level, are addressed only at one understanding of the 'environmental' citizen. By contrast, a more radical conception of 'ecological' citizenship may be advanced.

\section{'Environmental' Citizenship}

On the surface, there is little within the present formulation of citizenship as a concept of EU law that touches upon human-environment relations. At best, perhaps, citizenship suggests either a restricted, residual view of the 'market citizen', clv or of a political citizen enjoying political rights through bonds of residence and not mere nationality. On either approach, the interaction between the EU citizen and their environment is either indirect, through the market, or through a specific place or nation-centred participation in political life. We can, however, consider EC environmental law by looking at various tendencies suggested by the concept of citizenship. .lvi $^{\text {. }}$

Environmental law continues to eschew a full-blown rights perspective, ${ }^{\text {clvii }}$ and the Environmental Title of the EC Treaty continues to speak of "protecting the quality of the environment ${ }^{\text {'clviii }}$ rather than adopting a rights-based discourse as found elsewhere in the Treaty in relation to social and economic policy. ${ }^{\text {clix }}$ Similarly, the environmental action programmes have never emphasised rights in the way that, for example, consumer policy has. ${ }^{\mathrm{Cl}}$ Environmental policy remains more programmatic in character, based generally on duties of result owed by the Member States. Attempts during the 1996 IGC, both by Sweden and the Commission, to see a right of all citizens to a healthy environment inserted into the EC Treaty were unsuccessful, ${ }^{c \mid x i}$ although pressure for such a change may have been bought off only by the insertion of the new integration principle. . $^{\text {aii }}$

Grounding substantive environmental citizenship rights was again raised in the context of the latest IGC by environmental NGOs, ${ }^{\text {cxiii }}$ and featured in discussion over the draft Charter of Fundamental Rights. ${ }^{\text {ckiv }}$ Although the legal status of the Charter has yet to be determined, the only explicit mention of the environment adds nothing to the approach already taken in Article $6 \mathrm{EC}$ and no mention is made of environmental rights per se. ${ }^{\mathrm{clxv}}$ However, it must be doubted whether a legal right to environment, perhaps of the kind found in many national constitutions of Member States and accession countries, would operate at anything more than a policy level or provide anything more than symbolic capital. While the European Court of Human Rights has, in extreme cases, worked creatively with the European Convention on Human Rights to provide remedies for flagrant instances of environmental injustice, it has done so necessarily within existing categories of the protection of rights and freedoms. ${ }^{\text {clxvi }}$ It remains to be seen whether abstractlyformulated 'rights' in the context of the environment are useful, not least in relation to issues such as climate change and biodiversity conservation. By contrast to humanconstructed concepts such as freedom of trade or the right to equal treatment and freedom from discrimination, the environment is both a social construct and a practical reality; necessarily, our interaction with the environment, in its infinite variety of forms and qualities, means a weighting of complex economic, social and cultural values in the setting of environmental standards. clxvii As discussed above, so long as the objective is the integration of environment and economics through sustainable development, this requires some degree of resolution, rather than the 'trump' character of rights.

Legislatively, there appears to be a modest expansion of procedural rights. While access to EU documents is now provided for at Treaty level, ${ }^{\text {clxviii }}$ revisions to key directives such as on environmental impact assessment and the control of major accident hazards ${ }^{c \mid x i x}$ 
show an incremental enhancement of rights to information and participation. In the case of the latter, for example, Member States are now required proactively to publicise information relating to the more hazardous installations covered. Moreover, access to information (rather than merely access to documents) for any natural or legal person who so requests it follows the approach taken in the Directive on environmental information. ${ }^{c \mid x x}$ However, there is no fundamental change of approach from this Directive, namely to view procedural rights as facilitating enforcement, or at best enhancing transparency, rather than providing anything more free-standing. ${ }^{\text {clxxi }}$ These developments do little to challenge the framing of the EC's democratic difficulties primarily as questions of the balancing of power between the institutions rather than as about the relationship of 'citizens' to these institutions. .lxxii $^{\text {. }}$

There are some signs of a greater role for citizen-type involvement in EC decision-making, such as the emergence of limited attempts to foster an environmental civil society through EC funding for environmental NGOs operating at the European level. ${ }^{\text {clxiii }}$ Again, though, such funding may primarily assist the Commission, at least indirectly, in its enforcement role. In the same vein, the recent White Paper on Environmental Liability foresees a role for environmental NGOs, but only as a surrogate enforcement agency, generally where official action is not forthcoming. ${ }^{\text {clxxiv }}$ Where environmental NGOs have been given participatory rights at the level of EC decision-making, in practice these may be drowned out by the sound of industrial voices enjoying considerable numeric and other advantages. ${ }^{\text {.lxxv }} \quad$ Eventual implementation of the recently concluded 1998 Arhus Convention on Access to Information, Public Participation in Decision-Making and Access to Justice in Environmental Matters, though, may alter this significantly, providing a procedural complement to the more substantively-oriented but less environmentallyrelevant ECHR. But so far the environmental citizen, while demonstrably active across Europe (as evidenced by direct action style protest) is generally a passive voice in EC environmental law and policy. ${ }^{\text {clxxvi }}$

Perhaps the most interesting tangible developments in relation to environmental citizenship are taking place at judicial level. It is notable that the report of the European Court of Justice to the 1996 IGC specifically linked citizenship with its earlier creation of directly effective rights, suggesting that citizenship is to be seen substantively rather than merely in terms of procedural guarantees of political participation. ${ }^{\text {clxvii }}$ As with legislative action, however, the underlying concern with ensuring greater enforcement is being reflected in a drift away from the view that Community legislation will only be reviewable under the direct effect doctrine where there is detriment to an individual right. Thus, in two cases concerning the Directive on environmental assessment, the Court has held that what matters is the obligation on the Member State (or its competent authorities or even its courts) to take all the appropriate measures to ensure that the Directive is faithfully implemented in practice and that any discretion that a Member State has is not unduly exceeded. In the Kraaijeveld case, ${ }^{\mathrm{clxxviii}}$ a case concerning the lack of assessment of the environmental effects of constructing dykes, the Court held that the Member States' discretion in implementing the Directive in practice did not preclude judicial review of the question whether this discretion had been exceeded. The Court emphatically directed national courts to examine national legislation to see whether the legislative authorities have remained within the limits of their lawful discretion. The courts could therefore be obliged to set aside national legislation going beyond the limits of that discretion where they were bound to review the legality of national decision-making on their own motion. National authorities must then take all the measures necessary to ensure compliance with the Directive. Writing extra-judicially about Kraaijeveld, at least one member of the Court (Judge Edward) has tried to make it clear that this did not mean that the Court found this part of the environmental assessment Directive to be directly effective, or confer individual rights (thus ruling out Francovich claims). ${ }^{\text {clxxix }}$ 
In the more recent Bozen case, ${ }^{c \mid x x x}$ the Court was asked to consider a challenge to a decision not to require an impact assessment for redevelopment at Bolzano airport. The project would have changed the use of the airport from military to civilian and cargo flights, requiring some new development and intensifying effects from things like noise. The Court followed the Kraaijeveld case in holding that the key test in relation to such projects was whether they were likely to have significant environmental effects because of their size, nature or location, and did not explore the issue as to whether the applicants had any right to bring the case. Thus, while not holding that the Directive conferred directly effective rights on individuals where an authority in a Member State had exceeded its discretion, the Court provided a remedy for the applicants by, in effect, looking to the legality of the national decision-making procedure and the extent to which this, if unchecked, would detract from the effective implementation of the Directive.

Opinions differ on what is happening here. For some, following Judge Edward's lead, the Court is constructing a new remedy through which non-implementation of directives can be checked without opening up the possibility of state liability claims (termed by one commentator 'public law effect'). ${ }^{c \mid c x x i}$ For others, the better view would probably be to see this as an expansion of the direct effect doctrine, in part because of the practical difficulties in giving effect to any wider public law effect doctrine. ${ }^{\text {clxxxii }}$ In practical terms, however, the result is little different; the notion that an individual right must be infringed for a provision to be directly effective, and that a right based on the protection of human health, or compensation for economic loss arising from environmental 'harm', must be at stake (as against, say, 'interests' relating to nature conservation) ${ }^{\mathrm{cl} x x \mathrm{x} i i i}$ would seem to be being replaced by judicial mechanisms which look more towards the administrative duty that has been breached rather than the personal interests at stake. ${ }^{\text {clxxiv }}$ What is clear is that concerns about non-implementation of Community environmental law have driven the Court of Justice away from a narrow, rights-based citizenship-type agenda, expanding at the same time the concept of environmental citizenship, although still from an enforcement perspective.

A possible motivation behind the Court of Justice's approach appears to be self-interest in preventing an expansion in the workload of the Court in new areas. This is seen most clearly in the test for 'direct and individual concern' in Article 230 EC (ex Article 173), which the European Courts continue to interpret restrictively against individuals and environmental organisations, an interpretation which, perversely, operates so that the more widespread the environmental harm the stronger is the bar on legal recourse before the European Courts. This is the conclusion from Stichting Greenpeace Council, a challenge to the grant of regional assistance for the construction of two power stations in the Canary Islands. ${ }^{\mathrm{c} \times \mathrm{x} \times \mathrm{v}}$ The dilemma might also be seen as an attempt on the part of the Court to fit broad environmental concerns ('of general interest') into a tightly defined legal category, originally drawn up with the protection of discrete and individualised financial interests in mind. Nevertheless, the dissonance between seeking greater involvement of individuals and groups in the legislative process, whilst privileging the rights of only some of these participants in relation to the judicial interpretation or protection of the deals agreed, is striking, and of doubtful consistency with the requirements of the Århus Convention. ${ }^{\text {clxxxvi }}$ Outside of direct effect, the Court continues to be conspicuously inactive in the creative development of the procedural and participatory protections for individuals

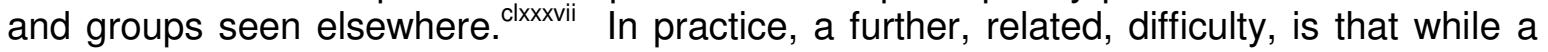
significant proportion (around one third) of ongoing enforcement action by the Commission relates to the environment, the Court is called upon comparatively rarely to rule on preliminary references in environmental matters, and when it does so these tend to be in cases brought by commercial rather than environmental concerns. ${ }^{\text {clxxxviii }}$ This has clear implications for the positive development of EC environmental law. 


\section{Towards 'Ecological’ Citizenship?}

Like citizenship generally, environmental citizenship has tended to be conceptualised in terms of the claiming of entitlements in the public sphere. These may be procedural rights of the kind discussed above, or more substantive rights to an environment of a 'clean', 'decent' or 'healthy' quality, framed anthropocentrically for humans. ${ }^{\text {clxxxix }}$ Theoretically, the exercise is often seen as expanding citizenship claims outwards from civic, political and social rights to 'third-generation' solidarity or collective rights such as environmental rights. Because EC law is an implicit rejection of ecological thought, however, an ecological perspective on citizenship arguably leads not to a 'mainstreaming' of EC environmental law but rather provides a 'disruptive challenge to traditional notions of citizenship', one which looks 'outside the city, beyond the public, and further afield than the nation-state'. ${ }^{x c}$

Various possibilities flow from taking an ecological citizenship perspective which, taking a duties-centred approach, is not based on a contract between the state and its members. ${ }^{\text {.xci }}$ Rather, we might consider EC environmental law as positing a conception of ecological citizenship neither wedded to the nation-state in space nor in time, nor wholly concerned with activities in the public sphere. Clearly, such an ecological citizenship poses a challenge even to the conceptions of citizenship that can be derived, immanently, from existing political, economic and social rights at EU level.

Initially, a duties-based approach is increasingly being pursued by commentators frustrated at attempts at ascribing environmental rights (and also 'rights to the environment' itself). ${ }^{\text {cxcii }}$ Moreover, duties-centred approaches can be found in some national constitutions of Member States, including duties both on individuals (e.g., the Spanish Constitution) and on government (e.g., the Dutch Constitution)). From an ecological perspective, a duties-based approach emphasises a degree of virtue, and an attitude towards the natural environment, and avoids any necessary connection with rights. By definition, environmental duties, owed across physical and spatial borders, cannot be based on reciprocity. ${ }^{\text {cxiii }}$

As far as law is concerned, three issues emerge in relation to duties. We might ask to whom a particular duty is owed, since this will be important for enforcement. Who has the correlative right to any duty placed either on the Commission or the Member States or on individuals? In Enichem Base, for example, the Court of Justice held that the Commission, not the Member State, had the correlative right in respect of reporting

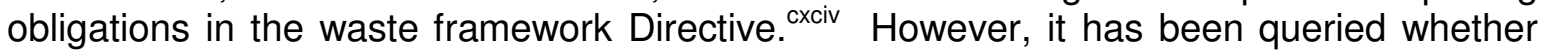
the same approach should be taken in a situation similar to that in the Stitching Greenpeace case, at least if the geographic nexus is sufficient to establish a right. ${ }^{\text {cxv }}$ Further, there may be greater flexibility in relation to transposing duties than rights; an obligation to prohibit an environmentally-damaging activity can generally be transposed either by criminal, civil or administrative mechanisms, and even within any of these categories there will generally be flexibility as to the degree of obligation, e.g., as between strict or fault-based liability. Finally, EC law can, directly or indirectly, regulate or stimulate private behaviour. There is, after all, much in the belief that 'from an ecological point of view, good citizenship is learnt in private, not in public'. cxcvi At least insofar as there is freedom in the domestic sphere (e.g., consumption and disposal) good ecological behaviour may be learnt in the private realm. EC law may further this aspect of ecological citizenship to the extent that such areas (waste; product labelling) are sites of legitimate EC involvement.

In relation to space, loosening the bonds between the citizen and the nation-state poses many of the same issues as the subsidiarity and flexibility debates, namely the legitimate extent of involvement in environmental and related affairs across Member State borders. ${ }^{\text {cxcvii }}$ Some strides have been made here, such as the revised Directive on environmental impact assessment which requires public consultation within other Member States which may experience significant environmental effects from developments outwith 
their borders. ${ }^{\text {cxcviii }}$ There is also some judicial support for the sufficiency of a geographic nexus in relation to enforcement proceedings under Article 230 EC. ${ }^{\text {cxcix }}$ Here, it might be noted that there is little citizenship-type involvement in relation to the external aspects of EC environmental law. To take trade as an example, a centralised approach prevails and, in cases where science is not the determinative discourse, a centralised view of institutionalised caution may dominate. ${ }^{\mathrm{Cc}}$ In general terms, there is much of an ecological nature that could usefully emerge from a European public space. ${ }^{\text {cci }}$

A further approach is through the concept of a common European natural heritage, discussed above. Although complex, the development of this concept may parallel the case of the free movement of persons in so far as there is evident a similar process of freeing legal action from an economic trigger in the interests of higher, aspirational ideas of citizenship arising from deeper integration in Europe. In a similar manner, we can see the flourishing of a more autonomous body of environmental law which, although bounded by economic considerations, is not attached umbilically to the single market. Ideas of a common natural heritage in Europe, whose articulation is symbolic and marginal to the conservation directives it underpins, ${ }^{\text {ccii }}$ ought therefore to elevate the relationship between community and environment to a higher plane, in the process creating a more direct connection between individuals and the environment. Without suggesting that such an approach is free from difficulties, articulated and generally accepted ecological duties, ${ }^{\text {cciii }}$ owed non-specifically across space and time, might avoid some of the difficulties inherent in what has been coined the 'psychic spillover' justification to EC environmental law, whereby issues of 'mere' concern to citizens in one Member State might justify regulating action in other Member States. ${ }^{\text {cciv }}$

\section{Conclusion}

European environmental law contributes to the construction of its subject by defining 'the environment' and drawing its boundaries; in this process it universalises its subject matter and plays an important symbolic role in the process of European integration. According to the Treaty, and increasingly in practice, sustainable development now provides the organising idea, or central reference point, not just for environmental law and policy but for all Community activities. Further legal principles (integration primarily, but also subsidiarity $^{\mathrm{ccv}}$ ) elaborate and give further expression to it. From a legal point of view, the process of 'mainstreaming' sustainable development and the other associated principles may lead to the application of legal doctrines and principles from social and economic policy areas to the environmental field. However, invoking law for environmental protection still raises problems peculiar to it. The broader issue is that, whilst locating principles of environmental law within mainstream EC law may provide a functional fit with the requirements of sustainable development, the essential and unique quality of environmental concern and thought might be lost, not the least of which are concerns relating to process and to identity which even the evolution of a type of European 'environmental' citizenship may neither capture nor replace.

\footnotetext{
* School of Law, Birkbeck College, University of London ** Faculty of Laws, University College London.

Thanks are due to Darren Abrahams for research assistance, and to the European University Institute who supported a period in Florence researching for this article. Thanks also for comments received following presentations of aspects of this work to the participants in the Environmental Law Section of the SPTL at the annual conference in Leeds, September 1999, and to staff and students at the Department of Land Economy, Cambridge, April 2000, and to Sue Elworthy, Chris Hilson and Joanne Scott for detailed comments.
} 
i Article 2 EC.

ii See: L. Krämer, EC Environmental Law (London: Sweet and Maxwell, 1999); A. Kiss and D. Shelton, Manual of European Environmental Law (Cambridge: Grotius, $2^{\text {nd }}$ ed, 1997); J. Scott, EC Environmental Law (London: Longman, 1998); C. Hilson, Regulating Pollution: A UK and EC Perspective (Oxford: Hart Publishing, 2000); G. Winter (ed.) European Environmental Law: A Comparative Perspective (Aldershot: Dartmouth, 1996); J. Jans, European Environmental Law (Dordrecht: Kluwer, $2^{\text {nd }}$ ed, 2000), D. Chalmers, 'Inhabitants in the Field of EC Environmental Law' in Craig and de Búrca (eds), The Evolution of EU Law (Oxford: Oxford University Press, 1999); and the Yearbook of European Environmental Law (Oxford, Oxford University Press), the first volume of which was published in 2000.

iii Although the precautionary principle is similarly undergoing a mainstreaming process, so far this change has been reflected only in policy rather than Treaty amendments. See Art.174(2) EC and Communication from the Commission on the Precautionary Principle, COM(2000)1.

iv Chalmers, $\mathrm{n} 2$ above, 674.

v Case 91/79 Commission v Italy [1980] ECR 1099; Case 92/79 Commission v Italy [1980] ECR 1115; Case C-240/83 Procureur de la République v Association de Défense des Brûleurs d'Huiles Usagées [1985] ECR 531.

vi On the evolution of EC environmental law and policy generally see E. Rehbinder and R. Stewart, 'Legal Integration in Federal Systems: European Community Environmental Law' (1985) 33 American Journal of Comparative Law 371; E. Rehbinder and R. Stewart, Environment Protection Policy (Berlin and New York: de Gruyter, 1985); P. Sands, 'European Community Environmental Law: The Evolution of a Regional Regime of International Environmental Protection' (1991) 100 Yale Law Journal 2511; Jans, $\mathrm{n} 2$ above, ch. 1; S. Elworthy and J. Holder, Environmental Protection: Text and Materials (London: Butterworths, 1997); ch 5; Chalmers, $\mathrm{n} 2$ above; Hilson, $\mathrm{n} 2$ above, ch. 000. In addition to general coverage, there is useful work disaggregating the factors behind individual Member States agreeing to this development, see especially J. Golub, 'British Sovereignty and the Development of EC Environmental Policy' (1996) 5 Environmental Politics 700.

vii For a strong view of 'ecological law', and a useful overview of the differences between environmental an ecological law see D. Wilkinson, 'Using Environmental Ethics to Create Ecological Law' in J. Holder and D. McGillivray (eds) Locality and Identity: Environmental Issues in Law and Society (Aldershot: Ashgate, 1999). See also $n 36$ below.

viii See generally D. Robinson and J. Dunkley, Public Interest Perspectives in Environmental Law (London: Wiley Chancery, 1995); C. Stone, Should Trees Have Standing?, and Other Essays on Law, Morals and the Environment, 25th anniversary ed. (Dobbs Ferry, N.Y.: Oceana, 1996); Holder and McGillivray, n 7 above; S. Bell and D. McGillivray, Ball and Bell on Environmental Law (London: Blackstone Press, 2000), esp. ch 2; and see also text at n 000 below.

ix See, similarly, Z. Bankowski and E. Christodoulidis, 'The European Union as an Essentially Contested Project' (1998) 4 European Law Journal 341.

${ }^{x}$ European Environment Agency, Environment in the European Union at the Turn of the Century (EEA, 1999), p.9 et seq.

xi These report that production and consumption look set to increase, with resultant increases of pollution and waste. The forecast, using a baseline, 'business as usual' scenario shows continued pressure on Europe's environment, European Environment Agency, ibid. See also the previous 'Dobris' and 'Dobris II' assessments (Europe's Environment: the Dobris Assessment (EEA, 1995) and Europe's Environment: the Second Assessment (EEA, 1998). Prior to the EEA, the Commission prepared a number of less sophisticated reports.

xii European Environment Agency, Report on the European Environment at the Turn of the Century, n 10 above, 2. This Report provides an assessment of the 'development of environmental quality in the EU in the near future, i.e. 2010'. The forecasts of environmental quality in various sectors, for example greenhouse gases and climate change, hazardous substances, soil degradation and 'water stress' are summarised by means of icons, showing either smiley faces, non-smiley faces or frowns. Each of the sectors listed above are portrayed by 'frowns'. 
xiii Although see Commission Communication on Sustainable Urban Development in the European Union: A Framework for Action, COM(1998) 605 final.

xiv On the indoor environment, see E. Shove, 'Threats and Defences in the Built Environment' in S. Elworthy et al (eds) Perspectives on the Environment 2 (Aldershot: Avebury, 1995).

${ }^{x v}$ On spatial scales and environmental thought, see David Harvey, Justice, Nature and the Geography of Difference (Oxford: Oxford University Press, 1996).

${ }^{x v i}$ For example, as a result of climate change; see P. D. Moore, B. Chaloner and P. Stott, Global Environmental Change (Oxford: Blackwell, 1996), ch.7; Wilkinson, 'Plants on the Move' 119 New Scientist (1999), 1 (Inside Science)

xvii A more tentative, but possibly more valuable, meaning may be suggested: "Environment" is ... whatever surrounds or, to be more precise, whatever exists in the surroundings of some being that is relevant to the state of that being at a particular place and time. The "situatedness" of a being and its internal conditions and needs have as much to say about the definition of environment as the surrounding conditions themselves, while the criteria of relevance can also vary widely.' Harvey, n 15 above, 118.

xviii For example, P. Macnaghten and J. Urry, Contested Natures (London: Sage, 1998).

${ }^{x i x}$ Environmental Signals 2000, available at http://themes.eea.eu.int/binary/s/signals2000.pdf

xx Proposals for a Sixth Environment Action Programme have been published as 'Environment 2010: Our future, Our choice', $\operatorname{COM}(2001) 31$ final, and include proposals for the use of environmental indicators (see para. 8.2). See further $n 66$ below. Community environmental law has been based on Environmental Action Programmes since 1973.

${ }^{x \times i} \operatorname{COM}(92) 22$ final, and see Council Resolution of 1 February 1993 on a Community programme of policy and action in relation to the environment and sustainable development (OJ C138 17.5.93 p1).

xxii See Quality of Life Counts (Department of the Environment, Transport and the Regions, December 1999), which includes crime statistics alongside indicators relating to air and water quality and other 'environmental' indicators, following on from A Better Quality of Life: A Strategy for Sustainable Development in the United Kingdom, Cm 4345, 1999.

xxiii See e.g. the dispute over whether the UK indicator for greenhouse gas emission reductions should be at 'green' (Quality of Life Counts, ibid) or 'red' (UK Round Table on Sustainable Development, Indicators of Sustainable Development, May 2000).

xxiv According to ideas of bioregionalism, the jurisdictions of national, and supranational governments match poorly with these areas, and so makes environmental governance difficult. That 'Europe' is not a single bioregion should create similar difficulties, however, in a contradictory fashion, European environmental policy has relied on the fit between the transboundary nature of environmental pollution and cross-border controls for its legitimacy.

${ }^{x \times v}$ For example, see the Commission Opinion on the motorway which intersects the Trebel and Recknitz Valley, OJ 1995, C178/3, discussed in A. Nollkaemper, 'Habitat Protection in European Community Law: Evolving Conceptions of a Balance of Interests' (1997) 9 Journal of Environmental Law 271. The European Environment Agency report, Environment in Europe at the Turn of the Century, n 10 above, documents the likely environmental effects of EU enlargement. Some accession countries have more environmentally sustainable economic activities and also more extensive areas of natural habitats. In the transition to EU membership there is a danger that 'their' environment will suffer if they follow the same development path of the existing members.

xxvi On 14 February 2000 negotiating Directives were adopted in Council under which all accession States are admitted to the European Environment Agency; on the negotiations see http://org.eea.eu.int/news.shtml. For judicial consideration of the extent of the European territory of the Member States in an environmental context see $R v$ Secretary of State for Trade and Industry ex parte Greenpeace (No. 2) [2000] Env LR 221.

xxvii See, e.g., Council Directive 83/189/EEC on seal pups (OJ 1983, L91/30), Council Regulation $348 / 81 /$ EEC on the import of whales and other cetacean products (OJ 1981 L39/1), and Council Regulation 3254/91/EEC on leghold traps (OJ 1991, L308/1). 
xxviii Although a balance between these two concerns has now been placed on a legislative footing by the adoption of Council Directive 91/676/EEC on the protection of waters against pollution caused by nitrates from agricultural sources (OJ 1991, L375/1).

xxix See, for example, the emphasis in Council Directive 91/271/EEC (OJ 1991, L135/40) on urban waste water treatment on dispersal rates. This extends to the judgments of the Court of Justice, in which it has interpreted directives with an 'environmental' objective in such a way as to suggest that their primary focus is human health. For example, in Case C-298/95 Commission v Germany [1996] ECR I-6747, Council Directive 78/659/EEC on freshwater fish waters (OJ 1978, L222/1) was interpreted in such a way since the species of fish covered were edible, notwithstanding that there is no authority for this in the Directive and that the Directive is classified by the EC as a conservation measure (see http://europa.eu.int/eur-lex/en/index.html). Arguably, the preamble is one of the first examples (at least in Community water law) where the ecological foundations for a Directive are stressed ahead of, or at least alongside, competition concerns.

${ }^{x \times x}$ Council Directive $92 / 43 / E E C$ on the conservation of natural habitats and of wild flora and fauna (OJ 1992, L206/7).

xxxi See Art. 6 of the Habitats Directive, ibid. This compares with a stricter approach to habitat protection under Council Directive 79/409/EEC on the conservation of wild birds (OJ 1979, L103/1), the key provision of which (Article (4)) is now repealed by the Habitats Directive.

xxxii Declaration of the United Nations Conference on the Human Environment (Stockholm, 1972), Principle 1: 'Man has the fundamental right to freedom, equality and adequate condition of life, in an environment of quality that permits a life of dignity and well being....'

xxxiii See discussion of ex Article 235 EEC (now Art. 308 EC) as an 'elastic clause' in J. Weiler, 'The Transformation of Europe' (1991) 100 Yale Law Journal 2403, 2443-2447.

xxxiv The Single European Act 1986 inserted a Title on the Environment in the EC Treaty. The Single European Act was concerned with environmental protection because of the distorting effects of differing national environmental laws on competition and intra-Community trade. A further influence was the likelihood of environmental harm caused by increased transportation, industrial restructuring and enhanced economic growth accompanying fulfilment of the internal market. Environmental policy, alongside social policy, came to be regarded by the Commission as a 'flanking' policy to complement the internal market. See Haigh and Baldock, Environmental Policy and 1992 (IEEP, 1992). We see, therefore, a non-linear development of EC environmental law - i.e. a corrective mechanism for the excesses of economic development. This might be compared with the more marginal use of 'free-standing' measures such as the Wild Birds Directive, Seal Pups Directive etc. prior to the insertion of the Environment Title in the EC Treaty 1986.

xxxv For example, the Directive on wild birds, particularly the sixth recital: '[W]hereas the conservation of the species of wild birds naturally occurring in the European territory of the Member States is necessary to attain, within the operation of the common market, of the Community's objectives regarding the improvement of living conditions, a harmonious development of economic activities throughout the Community and balanced expansion, but the necessary specific powers to act have not been provided by the Treaty;'.

xxxvi Weiler, n 33 above.

xxxvii The recent Council Directive 99/31/EC on landfill (OJ 1999, L182/1) does not address historic land contamination, and Council Directive 80/68/EEC on the protection of groundwater (OJ 1980, L20/43), which extends to indirect discharges to groundwater from disposal or tipping, only applies prospectively (Art. 5). The Commission's 1996 waste strategy expressed the view that remediation of such sites should be a matter primarily for the Member States (COM(96)399).

xxxviii Both of these areas, land development, or town and country planning, and energy persist in requiring unanimity in the Council, as do primarily fiscal measures (Art. 175(2) EC). Community competence is only implied through the statement of this fact in the Treaty. A proposed Directive on strategic environmental assessment of plans and programmes will, if adopted, impact upon the structure of decision-making in Member States' land development systems (see n 40 below and further text at $\mathrm{n} 97$ below).

${ }^{\text {xxxix }}$ See further A. Dobson, Green Political Thought (Routledge, 1995), $2^{\text {nd }}$ ed., ch. 1. 
${ }^{x l}$ On proposals for strategic environmental assessment see $\operatorname{COM}(96) 511$ and $\operatorname{COM}(99) 73$. SEA can be seen as the paradigm far-reaching legal instrument affecting the nature and culture of highlevel decision-making across numerous and disparate policy areas. The Council formally adopted a common position on 30 March 2000 (see http://europa.eu.int/comm/environment/eia/sealegalcontext.htm) and political agreement on a directive is expected in spring 2001 (see http://europa.eu.int/comm/environment/eia/sea-legalcontext.htm\#compos). See also text at $n 97$ below.

xli See e.g. Scott, n 2 above, ch.1 and Hilson, n 2 above, ch.000.

xlii N. Walker, 'Sovereignty and Differentiated Integration in the European Union', (1998) 4 European Law Journal 355, at 359.

xliii See Council Directive 85/337/EEC on the assessment of the effects on the environment of certain public and private projects (OJ 1985, L175/40) as amended by Council Directive 97/11/EC (OJ 1997, L73/5), Art. 7; Council Directive 96/62 on ambient air quality assessment and management (OJ 1997, L296/55), Art. 8(6); Council Directive 96/82/EC on major accident hazards (OJ 1997, L10/13), Art. 13; and Council Directive 2000/60/EC establishing a framework for Community action in the field of water policy (OJ 2000, L375/1), esp. Arts 11, 13 and 15.

xliv Council Directive 779/80/EEC on sulphur dioxide and suspended particles (OJ 1980, L229/30). See, e.g., Case C-361/88, Commission v Germany [1991] ECR I-2567.

xlv K. Gray, 'Equitable Property’ (1994) 47 Current Legal Problems 157, 206-207.

xivi See further text at $\mathrm{n} 000$ below.

xivii Case C-44/95 $R v$ Secretary of State for the Environment, ex parte RSPB [1996] ECR I-3805 ('Lappel Bank') at para. 23. The Court of Justice recounted the third recital of the Birds Directive which declares that migratory species 'constitute a common heritage' and that 'effective bird protection is typically a trans-frontier environment problem entailing common responsibilities'. See also Case C-339/87 Commission v Netherlands [1990] ECR I-851 in which the Court similarly speaks of 'common heritage'.

xlviii Case C-44/95, ibid, per Advocate General Fennelly.

xlix Case C-169/89 van den Berg [1990] ECR I-2143 at 2165. This 'localist' approach however was not not fully adopted by A-G van Gerven, who favoured the argument that the Directive supplied a legitimate basis for restricting trade in the birds because of the "transfrontier nature of the protection of birds" (at 2155)

'Emphasis added.

li Joined Cases C-164/97 and C-165/97 Parliament v Council [1999] ECR I-1139, para. 16: 'the natural heritage represented by forest ecosystems'. See also Council Resolution of 15 December 1998 on a forestry strategy for the European Union (OJ 1999, C56/1), which eschews the use of 'common heritage' language.

lii Article B of Title 1 of the Treaty on European Union.

liii World Commission on Environment and Development (The Brundtland Report), Our Common Future, (Oxford: Oxford University Press, 1987), 8. On the evolution of sustainable development as a legal concept see T. Jewell and J. Steele, 'UK Regulatory Reform and the Pursuit of Sustainable Development' (1996) Journal of Environmental Law.283; Elworthy and Holder, n 6 above, ch 4; J. Alder and D. Wilkinson, Environmental Law and Ethics (Basingstoke: Macmillan, 1999), 136-140 and ch 6; Kiss and Shelton, $\mathrm{n} 2$ above, ch. 2.

liv Most notably, in the Declaration to the 1992 Rio 'Earth Summit' and in Agenda 21.

Iv These organisations presented proposals for strengthening the environmental dimension of the EC Treaty in Greening the Treaty II: Sustainable Development in a Democratic Union, Proposals for the 1996 Intergovernmental Conference. See further N. Haigh, 'Introducing the Concept of Sustainable Development into the Treaties of the European Union' in T. O'Riordan and H. Voisey (eds), The Transition to Sustainability: The Politics of Agenda 21 in Europe (London: Earthscan, 1998). See also I. Christie, Sustaining Europe: A Common Cause for the European Union in the New Century (London: Demos/Green Alliance, 1999). 
Ivi See W. Beckerman, 'Sustainable Development: Is It a Useful Concept?' (1994) 3 Environmental Values 191; M. Jacobs, 'Sustainable Development, Capital Substitution and Economic Humility: A Response to Beckerman' (1995) 4 Environmental Values 57; H.E. Daly 'On Wilfred Beckerman's Critique of Sustainable Development' (1995) 4 Environmental Values.49; M. Redclift, Sustainable Development: Exploring the Contradictions (London: Routledge, 1989). On justice dimensions in particular see A. Dobson (ed.) Fairness and Futurity: Essays on Environmental Sustainability and Social Justice (Oxford: OUP, 1999) and A. Dobson, Justice and the Environment: Conceptions of Environmental Sustainability and Dimensions of Justice (Oxford: OUP, 1998).

Ivii Brundtland Report, $\mathrm{n} 53$ above, 8: '...aspects of technology and social organization can be both managed and improved to make way for a new era of economic growth'.

Iviii For a more thorough account, see M. Hajer, The Politics of Environmental Discourse: Ecological Modernisation and the Policy Process (Oxford: Clarendon Press, 1995). For an overview see A. Giddens, The Third Way: The Renewal of Social Democracy (Oxford: Polity Press, 1998), 000.

${ }^{l i x}$ For example, the inclusion of broad social policy objectives such as the anti-discrimination principle in Article $13 \mathrm{EC}$ (ex Art. 6a). This might be compared with the narrowly drawn principle of equality in Article 119 of the original Treaty of Rome (now Art. $141 \mathrm{EC}$ ) on equality between men and women in matters of pay for work.

${ }^{1 x}$ e.g. Case C-44/95 ('Lappel Bank'), n 47 above, in which the Court of Justice held that economic considerations can not influence the decision to designate an area for special protection for the purposes of the Wilds Birds Directive. See also Case C-371/98 $R v$ Secretary of State for the Environment, Transport and the Regions, ex parte First Corporate Shipping Ltd, Opinion of A.-G. Léger, 7 Mar. 2000, judgment of the Court 7 November 200, that economic considerations must be precluded when Member States draw up lists of candidate special areas of conservation under art.4(1) of the Habitats Directive, n 30 above. See also notes 71 and 77 below.

Ixi 'Sustainable and non-inflationary growth' is no longer expressly linked to or qualified by 'respecting the environment'. Also, the separate task of promoting the development of economic activities must now be 'sustainable' as well as harmonious and balanced. A new task of promoting a 'high level of environmental protection and improvement of the quality of the environment' is also inserted.

Ixii Council Regulation 722/97/EC (OJ 1997, L108/1) which refers to 'sustainable development' without directly defining it.

Ixiii Parliament and Council Regulation (EC) 2493/2000 on measures to promote the full integration of the environmental dimension in the development process of developing countries (OJ 2000, L288/1) Art. 2 (emphasis added).

Ixiv Article 174(1) EC.

${ }^{\text {Ixv }}$ See also the Partnership Agreement between the African Caribbean and Pacific States and the European Community and its Member States, non official and provisional version [ref to follow]

Ixvi See n 20 above. In Case C-142/95P Associazone agricoltori della provincia di Rovigo and Others v Commission [1996] ECR I-6669 the Court of Justice held that this action programme does not lay down any legal rules of a mandatory nature but provides merely a framework for the defining and implementing of Community environmental policy: 'For each of the main issues, long-term objectives are given as an indication of the sense of direction or thrust to be applied in the pursuit of sustainable development, certain targets are indicated for the period up to the year 2000 and a representative selection of actions is prescribed with a view to achieving the said targets. These objectives and targets do not constitute legal commitments but, rather, performance levels or achievements to be aimed at now in the interests of attaining a sustainable development path', point 12, Summary, Fifth Action Programme. This general approach is unlikely to change with the $6^{\text {th }}$ Environmental Action Programme, see n 20 above. Importantly, the Court was not asked, and did not take the opportunity to explore, the extent to which Towards Sustainability (64-70) looks to a broad range of instruments (economic, procedural, information-based etc) as necessary to achieve sustainability.

Ixvii See $n 43$ above. 
Ixviii E.g. Case C-72/95 BV Aannemersbedrijf PK Kraaijeveld and Others v Gedeputeerde Staten van Zuid-Holland [1996] ECR I-5403.

${ }^{\text {Ixix }}$ For example New Zealand $v$ France, ICJ Rep. 1995, 288, dissenting opinions of Judges Koroma, Palmer and Weeramantry. Judge Palmer advocates the recognition of environmental limits, including the calculus of risk via such mechanisms as environmental assessment, 'otherwise the paradigm of sustainable development enhanced by the world at the Rio Conference cannot be achieved' (para. 68). See also Case concerning the Gabcíkovo-Nagymaros Project (Hungary/Slovakia) (1998) 37 ILM 162 per Judge Weeramantry, who argues that sustainable development is not merely a concept but a recognised principle of customary international law, albeit one which suggests procedural rather than substantive obligations.

${ }^{1 \times x}$ See generally the Fifth Environmental Action Programme, Towards Sustainability, s 7.

Ixxi See $n 60$ above.

Ixxii See Case C-57/89 Commission v Germany [1991] ECR I-883 ('Leybucht Dykes); Case C355/90 Commission v Spain [1993] ECR I-4221 ('Santoña Marshes); Case C-44/95 R v Secretary of State for the Environment, ex parte RSPB (Lappel Bank, n 54 above). It is notable that under the Birds Directive, designation is a task solely for the Member States.

Ixxiii Although a key aspect of the principle, the integration principle, included in the Environment Title since 1986, may be seen as a precursor to sustainable development. See further below.

Ixxiv As proposed by the European Consultative Forum on the Environment and Sustainable Development (the European Commission's 'stakeholders' advisory forum on environment and sustainability).

Ixxv For example, consumer protection (Art. 153(2)), public health (Art. 152(1)) and culture (Art. 151(4)).

Ixxvi For example, the central concern of the Brundtland Report was the increasing globalisation of various crises (environmental, developmental, energy, etc), and the connections between them. As it memorably put it: 'They are all one'. This, of course, can be taken more narrowly than stronger theses relating to the connectedness of all life, on which see most famously B. Commoner, The Closing Circle (London: Cape, 1972).

Ixxvii This has been explicitly recognised by A-G Léger, see n 60 above: 'Integration of the environmental dimension is thus the basis of the strategy of sustainable development...'.

Ixxviii See generally Scott, $\mathrm{n} 2$ above, ch 7 .

Ixxix Case 302/86 Commission v Denmark [1988] ECR 4607 ('Danish Bottles'). More recently see Case C-389/96, Aher-Waggon GmbH v Germany [1998] ECR I-4473.

Ixxx Case C-67/97, Criminal proceedings against Bluhme [1998] ECR I-8033. For a useful review of the case law to Bluhme see H. Temmink, 'From Danish Bottles to Danish Bees: The Dynamics of Free Movement of Goods and Environmental Protection - a Case Law Analysis' (2000) 1 Yearbook of European Environmental Law 61.

Ixxxi P. Sands, 'The European Court of Justice: An Environmental Tribunal?' in H. Somsen (ed.) Protecting the European Environment: Enforcing EC Environmental Law (London: Blackstone, 1996). See further text at $n 000$ below.

Ixxxii On which see most notably the insertion, under the Treaty of Amsterdam, of the requirement that measures under the internal market environmental guarantee should not amount to "an obstacle to the functioning of the internal market", and criticism of the nebulousness of this: R. Macrory, 'Legal Issues of the Amsterdam Treaty: The Environment' in O'Keefe and Twomey (eds) Legal Issues of the Amsterdam Treaty (Oxford: Hart Publishing, 2000); H. Sevenster, 'The Environmental Guarantee After Amsterdam: Does the Emperor have New Clothes?' (2000) Yearbook of European Environmental Law 291.

Ixxxiii C. Harding, 'Who Goes to Court in Europe? An Analysis of Litigation against the European Community' (1992) 17 European Law Review 105; C. Harding and B. Swart (ed.), Enforcing European Community Rules: Criminal Proceedings, Administrative Procedures and Harmonization (Aldershot: Dartmouth, 1996); Chalmers, n 2 above; Jans, n 188 below. 
Ixxiv Article 130r(2) EEC: '...Environmental protection requirements should be a component of the Community's other policies'.

Ixxxv Article 130r(2) EC Treaty: '...Environmental protection requirements must be integrated into the definition and implementation of other Community policies'.

Ixxxvi Article 6 EC: 'Environmental protection requirements must be integrated into the definition and implementation of the Community's policies and activities referred to in Article 3, particularly with a view to promoting sustainable development'. See further Macrory, n 82 above.

Ixxxvii M. Hession and R. Macrory, 'The Legal Duty of Environmental Integration: Commitment and Obligation or Enforceable Right?' in T. O'Riordan and H. Voisey (eds) The Transition to Sustainability: The Politics of Agenda 21 in Europe (London: Earthscan, 1998).

Ixxxviii The conclusion of the Court of Justice in Case C-62/88, Parliament $v$ Council [1990] ECR I1527 ('Chernobyl I') was that the integration principle in its pre-Maastricht version implies that 'all community measures must satisfy the requirements of environmental protection' has been taken as hinting at 'more than a mere enabling provision' (Hession and Macrory, ibid).

Ixxxix Notwithstanding the Opinion of Advocate General Cosmas in Case C-321/95P Stichting Greenpeace Council (Greenpeace International) and others v Commission [1998] 3 CMLR 1 who was prepared to find that the integration principle was capable of direct effect, although the Court of Justice was silent on this point. Contrast transport policy: Case C13/83 Parliament v Council [1985] ECR 1513.s

${ }^{x c}$ For example, in Case C-300/89 Commission v Council (Titanium Dioxide) [1991] ECR I-2867 the Court of Justice considered that the principle of integration implied that 'a Community measure cannot be covered by Article 130s merely because it also pursues objectives of environmental protection'.

xci Hession and Macrory, n 87 above.

xcii See The Cologne Report on Environmental Integration: Mainstreaming of Environmental Policy, SEC(99)777.

xciii For example, Strengthening Environmental Integration within Community Energy Policy, COM(98)571 final, Indicators for the Integration of Environmental Concerns into the Common Agricultural Policy, COM(2000)20 final, Single Market and Environment, COM(99)263 final.

xciv Partnership for Integration - A Strategy for Integrating Environment into European Union Policies, COM(98) 333 final.

xcv G. van Calster and K. Deketelaere, 'Amsterdam, the Intergovernmental Conference and Greening the EU Treaty', (1998) 7 European Environmental Law Review 12 at 18. On 'Greening Government' see Bell and McGillivray, n 8 above, 000.

xcvi OJ 1999, L160/80.

xcvii See n 40 above. See recital 3: '...environmental assessment is an important tool in integrating environmental considerations into such plans and programmes because it ensures that the relevant authorities take account of the likely environmental effects of implementing plans and programmes prior to their adoption'.

xcviii Declaration 12 Treaty of Amsterdam, strengthening Declaration 20 Treaty of Maastricht.

xcix Directive 96/61/EC, OJ 1996, L257/26.

${ }^{c}$ S. Beckwith and J. Thornton, Environmental Law (London: Sweet and Maxwell, 1997), 142

${ }^{c i}$ See $n 43$ above.

cii See also, despite its voluntary nature, Council Regulation 1836/93/EEC on environmental management and audit (OJ 1993, L168/1) and calls for guidance, rather than legislation, on integrated coastal zone management (Towards a European Integrated Coastal Zone Management (ICZM) Strategy: General Principles and Policy Options; Lessons from the European Commission's Demonstration Programme on Integrated Coastal Zone Management (ICZM), both April 1999, and Towards a European Union Strategy for Integrated Coastal Zone Management, Seminar, Brussels, 2 July 1999. 
${ }^{\text {ciii }}$ E. Klatte, 'The Principle of Integration After 25 Years of Community Environmental Policy' (1999) 3 and 4 Law and European Affairs 370.

civ W. Sheate, 'From Environmental Impact Assessment to Strategic Environmental Assessment: Sustainability and Decision-Making' in J. Holder (ed.), The Impact of EC Environmental Law in the United Kingdom (London: Wiley, 1997). See also Commission Opinion (EC) 96/15, OJ 1996, L6/14 and draft Opinion 95/C OJ C78, p3 on the dissonance between transport and nature conservation objectives.

${ }^{c v}$ D. Baldock et al, The Integration of Environmental Protection Requirements into the Definition and Implementation of Other EC Policies (IEEP, 1992).

cvi Macrory, n 82 above, 174-175.

cvii 'The Community shall take action relating to the environment to the extent to which the objectives ... can be attained better at Community level than at the level of individual Member States'.

cviii Whether this takes 'situatedness' seriously must be doubted.

cix Golub, n 6 above, 714.

cx de Búrca, 'Reappraising Subsidiarity's Significance after Amsterdam', Harvard Jean Monnet Working Paper 7/99. See here also Protocol 30 to the EC Treaty on the application of the principles of subsidiarity and proportionality.

cxi See generally Scott, $\mathrm{n} 2$ above, $15-23$ and passim. It is notable that incisive reports on environmental law have come from the Court of Auditors, see e.g. Special Report No. 3/98 concerning the implementation by the Commission of EU policy and action as regards water pollution, OJ 1998, C191.

cxii For example, neither the Directive on landfill (n 37 above) nor the proposed Directive on environmental liability contain provisions for public participation (in relation to the latter, this might be contrasted with the US 'Superfund' rules concerning contaminated land).

cxiii G. Cross, 'Subsidiarity and the Environment' (1995) 15 Yearbook of European Law 107. “. . . an ever closer union among the peoples of Europe, in which decisions are taken as openly as possible and as closely as possible to the citizen." Article 1 TEU. On citizenship generally see page 000 below.

${ }^{\text {cxiv }}$ For example, in relation to environmental protection and external trade. For a more general overview of the problem of ascribing exclusive competence see de Búrca, n 110 above.

cxv n 43 above. See COM(93)28, and the criteria for assessment contained in the Protocol on the Application of the Principles of Subsidiarity and Proportionality, n 110 above. See also other information-based provisions on freedom of access to environmental information (Council Directive 90/313/EEC, OJ 1990, L158/56), eco-labelling (Council Regulation 880/92/EEC, OJ 1992, L99/1) and energy labelling (Council Directive 92/75/EEC, OJ 1992, L297/16) and environmental management and audit (see $\mathrm{n} 102$ above).

cxvi See, e.g., the action of the Parliament in rejecting the conclusions of the fiche d'impact in relation to the proposed Directive on landfill ( $\mathrm{n} 37$ above) that the Directive should not apply to rural areas, discussed in Froud, Boden, Ogus and Stubbs, Controlling the Regulators (Basingstoke: Macmillan, 1998), discussed in B. Lange, 'Economic Appraisal of Law-Making and Changing Forms of Governance' (2000) 63 Modern Law Review 294 at 298.

cxvii B. Flynn, 'Subsidiarity and the Rise of "Soft Law" in EU Environmental Policy: Beyond Who Does What, to What it is they Actually do?' (1997) European Policy Process, Occasional Paper No. 40.

cxviii See generally Scott, $\mathrm{n} 2$ above, chs 1 and 2 . 
cxix '[G]enerally the principle of subsidiarity has been complied with in Community environmental legislation', L. van Brinkhorst, 'Subsidiarity and European Community Environment Policy: A Panacea or a Pandora's Box?' (1993) 2 European Environmental Law Review 16 at 20 . See also Jans, $\mathrm{n} 2$ above, 11. Compare the remarks of Leon Brittan: 'Environmental policy should be the first target for subsidiarity', 'Subsidiarity in the constitution of the EC' Robert Schuman Lecture, 11 June 1992 (Florence, EUI), quoted in Golub, n 6 above.

cxx See Council Directive 98/83/EC (OJ 1998, L330/32), replacing Council Directive 80/778/EEC (OJ 1980, L.229/11) as from 25 December 2003 (longer periods are given for bromate, lead and trihalomethane).

cxxi See $\operatorname{COM}(94) 36$, amended proposal $\operatorname{COM}(97) 585$. For the latest proposals see now 'Developing a new Bathing Water Policy', COM (2000)860. A separate directive on bathing water survives the adoption of the Water Framework Directive, mentioned at n 43 above.

cxxii See $\mathrm{n} 43$ above

cxxiii Krämer, n 2 above, 206. The air quality sector in particular is notable for some quite radical approaches to standard-setting and national discretion; see especially Council Directive 88/609/EEC on large combustion plants (OJ 1988, L336/1) as amended, and comment by Scott, $n$ 2 above, 40 .

cxxiv See, e.g., the so-called 'hit lists' drawn up by the larger Member States, discussed in R. Axelrod, 'Subsidiarity and Environmental Policy in the European Community'(1994) 6 Journal of International Environmental Affairs 115; W. Wils 'Subsidiarity and EC Environmental Policy: Taking People's Concerns Seriously' (1994) 6 Journal of Environmental Law 85.

${ }^{c x x v}$ Respectively, Parliament and Council Directive 94/62/EC on packaging and packaging waste (OJ 1994, L365/10), and see $n 37$ above.

cxxvi See $\mathrm{n} 97$ above.

cxxvii $\operatorname{COM}(2000) 66$ final

cxxviii Council Directive 1999/22/EC relating to the keeping of wild animals in zoos (OJ 1999, L94/24), implementing in part the 1992 UN Convention on Biological Diversity. Krämer attributes the change of emphasis to a complete change of position by the UK, n 2 above, 147. The earlier proposals focusing on welfare considerations were on the verge of being watered down into a Council Recommendation, a draft of which appeared (COM(95)619). See also the resolution of the Parliament trying to prevent this downgrading (OJ C89, 10 April 1995 p234).

${ }^{\text {cxxix }}$ E.g. Council Directive 91/629/EEC laying down minimum standards for the protection of calves (O.J. 1991, L340/28); Various 'welfare' inspired measures on whales, seal pups and leghold traps are noted at $n 27$ above. See also Art. 9(5) of Council Regulation 338/97/EC, (OJ 1997, L61/1) which transposes welfare provisions in the CITES Treaty. Under Protocol 33 and Declaration No. 24 to the Amsterdam Treaty, regard to animal welfare is limited to CAP, transport, internal market and research, and the exclusion of EC environmental policy indicates that this provision applies only to domestic, not wild, animals.

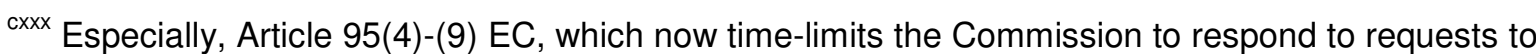
exceed harmonisation standards. Notably, the Directive on packaging waste, adopted under ex Article 100a, explicitly allows Member States to set higher recycling and recovery targets, and allows certain states to set lower targets, an interesting use of legal rather than financial flexibility measures (see Art.175(5)EC). Article 95 EC should be contrasted with Article 176 EC (ex Art. 130t) which, post-Amsterdam, continues to authorise measures to maintain or introduce more stringent protective measures.

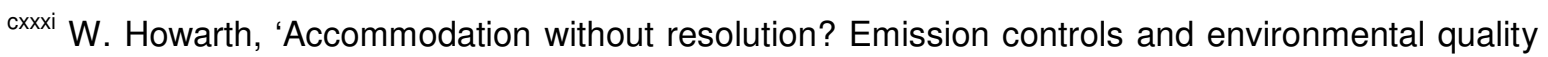
objectives in the proposed EC Water Framework Directive' (1999) 1 Environmental Law Review 6.

cxxxii Also in this context, Directive 96/61/EC on Integrated Pollution Prevention and Control (n 99 above) is notable; this is a framework directive in the sense that daughter directives must be agreed for certain categories of installations and polluting substances on the basis of information exchange between the Member States (Art. 18(1)). See, e.g., COM(97)604 on aqueous discharge from incineration of hazardous waste. 
cxxxiii E.g. the meaning of 'municipal' waste in the Directive on landfill, n 37 above.

cxxxiv See the IPPC Directive, n 99 above, which allows performance standards to be determined with regard to firms' 'geographic location and local environmental conditions', subject to meeting any relevant environmental quality standards; see further J. Scott, 'Flexibility, "Proceduralization", and Environmental Governance in the EU' in de Búrca and Scott (eds), The Changing Constitution of the EU: From Uniformity to Flexibility? (Oxford: Hart Publishing, 2000).

cxxxv E.g. $R \vee$ Secretary of State for the Environment, ex parte Kingston upon Hull City Council [1996] Env LR 000.

cxxxvi Case C-3/96 Commission v Netherlands [1998] ECR I-3031.

cxxxvii Contrast Case C-225/96 Commission v Italy [1997] ECR I-6887 (shellfish waters) with Case C293/97, R v Secretary of State for the Environment and Minister of Agriculture, Fisheries and Food ex parte Standley and Metson [1999] ECR I-2603 (designation of nitrate vulnerable zones). In the latter, the Court of Justice held that 'Community law cannot provide precise criteria for establishing in each case whether the discharge of nitrogen compounds of agricultural origin makes a significant contribution to the pollution .... The Directive may thus be applied by the Member States in different ways' (paras 38 and 39).

cxxvviii See $\mathrm{n} 28$ above.

cxxix Note 137 above, paras 38 and 39.

${ }^{c x l}$ Chalmers, $\mathrm{n} 2$ above, 679. In particular, enforcement of the Directive on environmental impact assessment (n 75 above) proved contentious; see P. Kunzlik, 'Environmental Impact Assessment: The British Cases' (1995) 4 European Environmental Law Review 336; R. Williams, 'The European Commission and the Enforcement of Environmental Law: an Invidious Position' (1994) Yearbook of European Law 351. As the Commissioner responsible at the time (Carlo Ripa di Meana) remarked, 'Whenever we discussed subsidiarity in the commission, I saw Delors glaring at me', in C. Grant, Delors: Inside the House that Jacques Built (London: Nicholas Brealey, 1994), at 108.

cxli Conseil 99/409, Brussels, 13/14 December 1999, available at www.asser.nl/EEL/index4.htm. As with IMPEL, however, the proposed criteria would only apply to industrial activities, not environmental law more generally.

cxlii See, e.g., the Commission statement attached at to Directive $98 / 70 / E C$ relating to the quality of petrol and diesel fuels (OJ 1998, L350/58).

cxliii $\operatorname{COM}(98) 495$ final (European manufacturers); $\operatorname{COM}(99) 446$ final (Japanese and Korean manufacturers).

cxliv Amongst current proposals see proposals for an integrated products policy. Notably the water framework directive, n 43 above, requires 'full-cost' water charging as from 2010. Markets may, however, emerge in response to EC environmental legislation, as has been the case, at least in the UK, with the market in packaging waste recovery notes following implementation of the Directive on packaging waste, n 125 above and generally Bell and McGillivray, n 8 above, 201. There is the prospect of an emissions trading system emerging within the EC, as provided for under the 1997 Kyoto Protocol to the 1992 UN Framework Convention on Climate Change.

${ }^{\text {cxlv }}$ See $\operatorname{COM}(92) 266$ final, as amended, and $\operatorname{COM}(97) 30$. See also $n 38$ above.

cxlvi $\operatorname{COM}(2000) 87$.

cxlvii de Búrca, n 110 above.

cxlviii See, e.g., the conference in September 1993 on future directions for drinking water, see J. Richardson, 'EU Water Policy: Uncertain Agendas, Shifting Networks and Complex Coalitions' (1994) 3 Environmental Politics 139, 140, and contrast the 'Auto-Oil' programme.

cxlix e.g., the Landfill Directive (n 37 above) and proposals on environmental liability (n 127 above).

${ }^{c l}$ Chalmers, $\mathrm{n} 2$ above, 681.

cli Council Directive 94/45/EC (OJ 1994, L254/64). 
clii On citizenship in an EC environmental law context see $n 113$ above and R. Macrory, 'Environmental Citizenship and the Law: Repairing the European Road' (1996) 8 Journal of Environmental Law 219.

cliii Ex Article 8a-e EC, now Articles 18-22 EC, described as 'an embarrassment', 'an empty gesture', 'little more than a cynical exercise in public relations' and ultimately 'a failure of the imagination': see Weiler, 'The Selling of Europe: the Discourse of European Citizenship in the IGC 1996' (1996).

cliv See Implementing Community Environmental Law: Commission Communication to Council and Parliament, COM(96)500 final.

clv M. Everson, 'The Legacy of the Market Citizen', in J. Shaw and G. More (eds) New Legal Dynamics of the European Union (Oxford: Oxford University Press, 1996). On this, see, for example, the problematic eco-labelling and energy labelling regimes, n 000 above.

clvi J. Shaw, 'The Interpretation of European Union Citizenship' (1998) 61 Modern Law Review 293.

clvii Despite its partial origins in the Stockholm Conference, and Principle 1 of the Stockholm Declaration that 'Man has the fundamental right to freedom, equality, and adequate conditions of life, in an environment of a quality that permits a life of dignity and well-being'.

clviii Article 174(1) EC (ex Article 130r(1)).

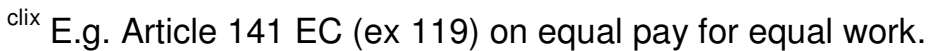

${ }^{c \mid x}$ N. Reich, 'The Recognition of Fundamental Rights in the Areas of Consumer and Environmental Protection by the EC' in C. Kye (ed.) EU Environmental Law and Policy and EU Consumer Law and Policy: Converging and Diverging Trends (Dordrecht: Kluwer, 1995). There was no mention of 'environmental rights' in the first three environmental action programmes.

clxi A. Jordan, 'Step Change or Stasis? EC Environmental Policy after the Amsterdam Treaty' (1998) 7 Environmental Politics 227.

clxii Macrory, $\mathrm{n} 82$ above. See generally text at $\mathrm{n} 000$ above.

clxiii Birdlife et al, Greening the Treaty III: Institutional Reform, Citizen's Rights and Sustainable Development. Proposals for the 2000 Intergovernmental Conference (at www.eel.nl).

clxiv See the right to respect for the environment contained in the European Parliaments Draft Constitution of the EU (adopted 1994), in the Parliament's Imbeni Report on Union Citizenship for the European Parliament's Committee on Civil Liberties and Internal Affairs (Doc. A3-0437/93, 21.12.93), and in the Bindi Report on European Citizenship for the European Parliament's Institutional Affairs Committee (DOC A3-0300/91) (referred to ibid, 123). On previous attempts see K. Lanaerts, 'Fundamental Rights to be Included in a Community Catalogue' (1991) 16 European Law Review 367.

${ }^{c}$ A $A$ high level of environmental protection and the improvement of the quality of the environment must be integrated into the policies of the Union and ensured in accordance with the principle of sustainable development (Article 37).

clxvi See Lopez Ostra v Spain (1995) 20 EHRR 277, Guerra v Italy [1998] 26 EHRR 357. But contrast unsuccessful cases not involving property rights, e.g. LCB v UK (1999) 27 EHRR 212.

clxvii Royal Commission on Environmental Pollution, $21^{\text {st }}$ Report, Setting Environmental Standards, Cm 4053 (1998). For specific criticism of environmental rights see Macrory, n 152 above; C. Miller, Environmental Rights: Critical Perspectives (London: Routledge, 1998); P. Eleftheriades 'The Future of Environmental Rights in the EU' in P. Alston (ed.) The European Union and Human Rights (Oxford: Oxford University Press, 1999).

clxviii Article 255 EC. See also Decision of 21 March 1997, O.J. 1997, C282/5, which governs access to documents emanating from the European Environment Agency.

clxix See $\mathrm{n} 43$ above.

clxx ibid, Article 20(1). See also Directive 90/313/EEC, n 115 above, Art.3.

clxxi The information directive can also be seen as serving to correct the sub-optimal provision of information by the market; information is thus promoted as an alternative regulatory mechanism in 
itself. See generally V. Heyvaert, 'Access to Information in a Deregulated Environment', in U. Collier (ed.), Deregulation in the European Union: Environmental Perspectives (London: Routledge, 1998). We doubt whether this does more than further underscore the 'market citizen' model.

${ }^{c l x x i i}$ R. de Lange, 'Paradoxes of European Citizenship' in P. Fitzpatrick (ed.) Nationalism, Racism and the Rule of Law (Aldershot: Dartmouth, 1995) 97 at 99; K. Armstrong, 'Citizenship of the Union? Lessons from Carvel and the Guardian' (1996) 59 Modern Law Review 582 at 588.

clxxiii Council Decision 97/872/EC (OJ 1997, L354/25), which applies for the years 1998-2001. It should be noted, though, that Commission support for environmental NGOs has gone on for longer than this measure, albeit often indirect through the staging of conferences etc.

clxxiv See $n 127$ above.

clxxv See in particular Council Directive 96/61/EC, n 99 above, art.16(2).

clxxvi See $\operatorname{COM(2000)155:~'working~for~the~citizen'~(para.~3).~}$

clxxvii Report of the Court of Justice (and Court of First Instance) on Certain Aspects of the Application of the Treaty on European Union, May 1995.

clxxviii Note 68 above.

clxxix See the Foreword to Holder (ed.) n 104 above, p.3.

clxxx Case C-435/97 World Wildlife Fund and Others v Autonome Provinz Bozen and Others [2000] 1 CMLR 149.

clxxxi Scott, n 2 above, 157.

clxxxii C. Hilson and T. Downes, 'Making Sense of Rights: Community Rights in EC Law' (1999) 24 European Law Review 121. This argues that direct effect can be established so long as effect utile is at stake. This work provides a challenging critique and persuasive basis for laying a doctrinal foundation to the important normative issues at stake in relation to diffuse, impersonal interests such as those relating to the environment.

clxxiii For an overview of the case law see generally C. Hilson, 'Community Rights in Environmental Law: Rhetoric or Reality?' in Holder (ed.), n 104 above.

clxxxiv In this sense, mirroring developments in environmental judicial review at the English national level; see $R$ v Somerset County Council, ex p Dixon [1998] Env LR 111. At national level, there has also been welcome recognition that the extent to which directives cannot be directly effective because they sought to be applied horizontally between individuals must be given a restricted understanding in those 'tripartite' (or 'indirect horizontal effect') situations where an individual seeks to enforce a procedural environmental right against a Member State which leads to negative consequences for another individual, see $R v$ Durham CC, Sherburn Stone Company Ltd \& Secretary of State for Environment, Transport and the Regions, ex parte Huddleston [2000] 2 CMLR 313 and comment by Stallworthy at 2 Environmental Law Review (2000) 102.

clxxvv Case C-321/95P Stichting Greenpeace Council, n 89 above. See also Case T-461/93 An Taisce and WWF v Commission [1994] ECR II-733, ECJ and generally Krämer 'Public Interest Litigation in Environmental Matters Before European Courts' 8 Journal of Environmental Law (1996) 1. To date Article 302 (ex 175) has never been used in an environmental context.

clxxxvi Especially Art. 9(3).

clxxvii For example, the International Court of Justice, n 69 above. These developments have largely been through dissenting opinions. The Greenpeace judgment, n 89 above, suggests thinlyconcealed differences of judicial opinion which might better be brought to the surface.

clxxxviii J. Jans, presentation at the conference Sustaining Environmental Law, Imperial College, London, 10 October 1998.

clxxxix Notable here is the European Council's Dublin Declaration on 'the Environmental Imperative' (June 1990), which endorsed the right to a clean and healthy environment for the citizens of the European Union. 
${ }^{c x c}$ A. Dobson, 'Ecological Citizenship: A Disruptive Influence?' Paper presented at the University of Reading, 24 November 1998, 19 and 20.

cxci On the traditional link between citizenship and state see S. O'Leary, European Union Citizenship: Options for Reform (London: IPPR, 1996), 10 (citizenship as the 'internal reflection of state membership'); U. Preuß , 'Problems of a Concept of European Citizenship' (1995) 1 European Law Journal 267; R. Dahrendorf, 'The Changing Quality of Citizenship', in B. van Steenbergen (ed.), The Condition of Citizenship (London: Sage, 1994), 18.

cxcii See, e.g., Miller, n 167 above.

cxciii Dobson, n 190 above.

cxciv Case C380/87 Enichem Base v Comune di Cinisello Balsamo [1989] ECR 2491. Member States' compliance levels with reporting obligations is generally very poor. See, e.g., D. Wilkinson, The State of Reporting by the EC Commission in Fulfilment of Obligations Contained in EC Environmental Legislation (London: Institute of European Environmental Policy, 1994).

${ }^{\mathrm{cxc}}$ See further Hilson and Downes, n 182 above.

cxcvi Dobson, n 190 above, 20. Dobson makes an additional point that the virtues of care and compassion, which he considers necessary to ecological citizenship, are also principally learnt in the private realm.

cxcvii This dimension need not necessarily be approached through concepts of citizenship but doing so with regard to implied citizenship duties is more fruitful; A. Weale, 'Citizenship Beyond Borders', in U. Vogel and M. Moran (eds) The Frontiers of Citizenship (Basingstoke: Macmillan, 1991), 155.

cxcviii Note 43 above, Art. 7, implementing the 1991 'Espoo' Convention on Environmental Impact Assessment in a Transboundary Context. This strengthens the limited transboundary notification provisions in the original directive. See also the 'Seveso II' Directive, n 161 above, Art. 13 (information on safety measures).

cxcix Case C-321/95P Stichting Greenpeace Council, n 89 above per Advocate General Cosmas.

${ }^{c c}$ See, e.g., the Communication from the Commission on the Precautionary Principle, $\operatorname{COM}(2000)$ 1.

cci Drawing on J. Weiler, 'European Citizenship and the Post-Maastricht Debate' Harvard Jean Monnet Working Paper 3/96.

ccii On wild birds and habitats, see notes 30 and 29 above respectively.

cciii Reaching agreement on what such duties are would require public consent, indicating the connections between public and private in this respect.

cciv See Wils, n 124 above; for critique see Scott, n 2 above.

${ }^{c c v}$ And similarly in relation to precaution, on which see $\mathrm{n} 3$ above. 